\title{
Methodiek voor korte-termijn arbeidsmarktprognoses op basis van een stromenmodel
}

Citation for published version (APA):

Vlasblom, J. D., \& Diephuis, B. J. (2000). Methodiek voor korte-termijn arbeidsmarktprognoses op basis van een stromenmodel. Researchcentrum voor Onderwijs en Arbeidsmarkt, Faculteit der Economische Wetenschappen. ROA Working Papers No. 4 https://doi.org/10.26481/umarow.2000004

Document status and date:

Published: 01/01/2000

DOI:

10.26481/umarow.2000004

Document Version:

Publisher's PDF, also known as Version of record

\section{Please check the document version of this publication:}

- A submitted manuscript is the version of the article upon submission and before peer-review. There can be important differences between the submitted version and the official published version of record.

People interested in the research are advised to contact the author for the final version of the publication, or visit the DOI to the publisher's website.

- The final author version and the galley proof are versions of the publication after peer review.

- The final published version features the final layout of the paper including the volume, issue and page numbers.

Link to publication

\footnotetext{
General rights rights.

- You may freely distribute the URL identifying the publication in the public portal. please follow below link for the End User Agreement:

www.umlib.nl/taverne-license

Take down policy

If you believe that this document breaches copyright please contact us at:

repository@maastrichtuniversity.nl

providing details and we will investigate your claim.
}

Copyright and moral rights for the publications made accessible in the public portal are retained by the authors and/or other copyright owners and it is a condition of accessing publications that users recognise and abide by the legal requirements associated with these

- Users may download and print one copy of any publication from the public portal for the purpose of private study or research.

- You may not further distribute the material or use it for any profit-making activity or commercial gain

If the publication is distributed under the terms of Article $25 \mathrm{fa}$ of the Dutch Copyright Act, indicated by the "Taverne" license above, 


\title{
Methodiek voor korte-termijn arbeidsmarktprognoses op basis van een stromenmodel
}

\author{
ROA-W-2000/4
}

Jan Dirk Vlasblom en Bart J. Diephuis

\section{Researchcentrum voor Onderwijs en Arbeidsmarkt}

Faculteit der Economische Wetenschappen en Bedrijfskunde Universiteit Maastricht

Maastricht, februari 2000 
ISBN 90-5321-287-6

Sec00.031/JDV 
Inhoud

Bladzijde

Voorwoord

$1 \quad$ Inleiding

$2 \quad$ Gebruiksdoelen van kortetermijnprognoses 3

2.1 Inleiding

3

2.2 Scholingsbeleid

$\underline{2.3}$ Bemiddelingsbeleid 4

2.4 Loopbaanoriëntatie

$\underline{\underline{2.5}} \underline{\text { Samenvatting en conclusie }} \quad 6$

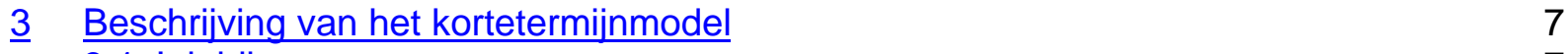

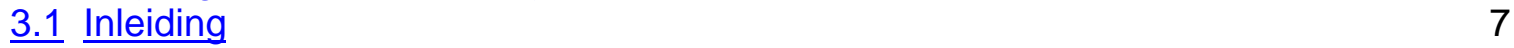

3.2 De stromen op de arbeidsmarkt $\quad 7$

$\underline{3.3}$ Het prognosemodel 13

$\underline{3.4}$ De relatie met het middellangetermijnmodel 16

$4 \quad$ Empirische specificatie van het model 17

$\begin{array}{ll}4.1 & \text { Inleiding } \\ 4.2 & 17\end{array}$

$\underline{4.2}$ De econometrische specificatie $\quad 18$

$\underline{4.3}$ Het gehanteerde aggregatieniveau $\quad 22$

$\underline{4.4}$ Empirische resultaten 24

$\underline{5}$ Prognoses $\quad 30$

5.1 Inleiding 30

$\underline{5.2}$ Verwachte overschotten en tekorten $\quad 30$

$\underline{5.3}$ De verwachte brutostromen $\quad 32$

$\underline{5.4}$ Verwachte baanmobiliteit $\quad 40$

$\underline{5.5}$ Gebruiksmogelijkheden van de prognoses $\quad 41$

$\underline{6} \quad$ Conclusies en suggesties voor een verdere ontwikkeling 43

$\begin{array}{lr}\text { Literatuur } & 47\end{array}$ 



\section{Voorwoord}

Dit werkdocument maakt deel uit van het Project Onderwijs-Arbeidsmarkt (POA). Dit project wordt gefinancierd door het Ministerie van Onderwijs, Cultuur en Wetenschappen, Arbeidsvoorziening Facilitair Bedrijf, het LDC Expertisecentrum voor Loopbaanvraagstukken en het Ministerie van Landbouw, Natuurbeheer en Visserij.

In toenemende mate bestaat er behoefte aan arbeidsmarktprognoses voor de korte termijn. In dit werkdocument vindt een verkenning plaats van de informatie die dergelijke prognoses op moeten leveren. Daarnaast wordt een methodiek gepresenteerd die gebruikt zal worden om kortetermijnprognoses te genereren. 


\section{Inleiding}

Om- en bijscholing van dat deel van de (potentiële) beroepsbevolking dat niet onmiddellijk inzetbaar is, kan een effectief middel zijn om de discrepanties tussen vraag en aanbod en daarmee de knelpunten in de personeelsvoorziening te verminderen. Dit vereist dan wel een prognose van de knelpunten die zullen ontstaan. Op basis van deze prognoses kunnen bijvoorbeeld de Arbeidsvoorzieningsorganisatie en werkgevers tijdig scholingsprogramma's opzetten om het ontstaan van deze knelpunten te voorkomen, of de ernst van de knelpunten in ieder geval zo klein mogelijk te houden.

Bij dit type kortdurende om- en bijscholing gaat het overigens niet alleen om de scholing van werkzoekenden of niet-participerenden. Ook scholing van werkenden kan een belangrijke rol spelen bij het verminderen van de knelpunten in de personeelsvoorziening. Lang niet alle banen kunnen vervuld worden door 'nieuwkomers' op de arbeidsmarkt. Voor de vervulling van sommige functies zijn mensen nodig met werkervaring. Door werkenden te scholen, kan de doorstroming naar dergelijke functies verbeterd worden, zodat enerzijds mogelijke knelpunten op de hogere functies verminderd kunnen worden, terwijl aan de andere kant functies op een lager niveau beschikbaar komen voor de 'nieuwkomers' op de arbeidsmarkt. Een dergelijk model van doorschuiven van vacatures naar lagere niveaus of andere richtingen wordt ook wel aangeduid met de term 'cascademodel'. De informatie over de op korte termijn verwachte ontwikkelingen op de arbeidsmarkt is hierdoor ook van belang voor de loopbaanoriëntatie van werkenden.

Het type scholingsprogramma's dat door bijvoorbeeld de Arbeidsvoorzieningsorganisatie gehanteerd wordt om knelpunten te voorkomen of te verminderen is vaak gericht op de korte termijn (dat wil zeggen: één, hooguit twee jaar vooruit). De prognoses die het ROA tot op heden in het kader van het Project Onderwijs-Arbeidsmarkt opstelt, bestrijken echter een veel langere periode, namelijk een periode van vijf jaar (zie ROA, 1999). Kortetermijnprognoses van de vraag- en aanbodontwikkelingen op de arbeidsmarkt en de daaruit resulterende discrepanties op de arbeidsmarkt zouden derhalve aanvullend daarop waardevolle arbeidsmarktinformatie kunnen genereren. Overigens is scholing niet het enige gebruiksdoel waar deze prognoses voor gebruikt kunnen worden. Er zijn meerdere doelen denkbaar waarvoor een dergelijk kortetermijnmodel richting gevende informatie zou kunnen geven. De drie belangrijkste doelen lijken te zijn:

- de scholing van (niet direct inzetbare) werkzoekenden en werkenden;

- de bemiddeling tussen vraag en aanbod op de arbeidsmarkt;

- de loopbaanoriëntatie.

In het bijzonder voor de Arbeidsvoorzieningsorganisatie vervullen de kortetermijnprognoses overigens niet alleen een rol bij de scholingsplanning en het bemiddelingsbeleid, maar ook voor de algehele beleidsplanningscyclus, de taakstellingen voor de arbeidsvoorzieningsgebieden, de vacaturewerving, sectorstudies, e.d. (zie De Grip, 1993).

Gegeven deze drie hoofddoelen van de kortetermijnprognoses, zal in dit werkdocument een verkenning plaatsvinden van de informatiebehoefte. Daarnaast speelt de vraag op welk 
aggregatieniveau deze informatie beschikbaar moet zijn. Vervolgens zal nagegaan worden in hoeverre het mogelijk is om een korte-termijn prognosemethodiek te ontwikkelen die in staat is dergelijke informatie te genereren.

Vanwege het feit dat loopbaanoriëntatie tot de gebruiksdoelen behoort, en ook dat scholingsprogramma's en bemiddeling op een individueel niveau afspelen, lijkt het voor de hand te liggen in eerste instantie na te gaan in hoeverre er een model ontwikkeld kan worden dat opereert op dit individuele niveau. Baan-baanmobiliteit, loopbaanontwikkelingen, regionale mobiliteit, concurrentieverhoudingen tussen diverse groepen op de arbeidsmarkt lijken gezien de gebruiksdoelen van belang te zijn. Ook binnen het onderzoeksprogramma van het Project Onderwijs-Arbeidsmarkt is in een aantal ontwikkeltrajecten tot de conclusie gekomen dat er meer bekend moet worden over dergelijke brutostromen op de arbeidsmarkt (o.a. De Grip e.a., 1999a). Het middellangetermijnmodel dat tot nu toe gehanteerd wordt, is echter een nettostromenmodel dat over dit type vragen niet goed uitsluitsel kan geven omdat het alleen uitspraken doet over nettoverschuivingen in vraag en aanbod.

Het brutostromenmodel dat in deze studie ontwikkeld zal worden, gaat uit van veranderingen op individueel niveau. Dit model zal veel meer dan met het huidige model voor de middellangetermijnprognoses het geval is, de nadruk kunnen leggen op micro-economische aspecten van de arbeidsmarkt door de individuele werknemer, schoolverlater, etc. als uitgangspunt te nemen. Hierdoor is het veel beter in staat uitspraken te doen over de vraag wie er van beroep of baan verandert. Het is op basis van een dergelijk model dus makkelijker om uitspraken te doen over onderlinge concurrentieverhoudingen van aanbieders op de arbeidsmarkt. Binnen een dergelijk model is het ook mogelijk een relatie te leggen tussen de arbeidsmobiliteit, de werkzoekenden- en vacaturecijfers en de daaraan ten grondslag liggende vraag- en aanbodontwikkelingen op de arbeidsmarkt. Daardoor kan een indicatie verkregen worden van de lengte van de zogenaamde vacatureketens waardoor er een relatie gelegd kan worden tussen het aantal vacatures en het aantal baanopeningen voor nieuwkomers, zoals dat op basis van het middelllangetermijnmodel wordt voorspeld. Dit is met name belangrijk als de prognoses bedoeld zijn voor andere doelgroepen dan de studiekiezers in het initieel onderwijs.

Door de brutostromen te aggregeren kan - net zoals in het middellangetermijnmodel - per opleiding of beroep een discrepantie tussen vraag en aanbod bepaald worden. Door deze informatie te koppelen aan de informatie over de concurrentieverhoudingen tussen de verschillende groepen die zich aanbieden op de arbeidsmarkt, kan er nagegaan worden wie het meeste baat heeft van scholing, en welke scholing dit zou moeten zijn (zie De Grip e.a., 1999a). Door dit andere uitgangspunt kan het te ontwikkelen model op termijn ook op andere punten een nuttige aanvulling zijn op het huidige middellange-termijn prognosemodel. Aan de andere kant kan een nieuw model ook een nuttig referentiepunt opleveren voor het huidige model. 


\section{Gebruiksdoelen van kortetermijnprognoses}

\subsection{Inleiding}

Kort samengevat zijn er drie doelen voor de kortetermijnprognoses: het scholingsbeleid, bemiddeling tussen vraag en aanbod op de arbeidsmarkt en loopbaanoriëntatie. Van elk van deze drie doelen zal in dit hoofdstuk aangegeven worden welke informatie beschikbaar zou moeten zijn. Het zal blijken dat de drie gebruiksdoelen niet onafhankelijk van elkaar zijn: scholing en loopbaan zijn in hoge mate gekoppeld. Niet alleen op individueel niveau, maar ook op een hoger, geaggregeerd niveau: als hoger opgeleiden doorstromen naar andere functies, schept dat aan de 'onderkant' ruimte voor lager opgeleiden. In de volgende drie paragrafen worden de drie afzonderlijke gebruiksdoelen verder uitgewerkt. In de laatste, afsluitende, paragraaf wordt aangegeven welke informatie met het model in principe gegenereerd zou moeten kunnen worden. De vraag of deze informatie gegenereerd kan worden, komt in de volgende hoofdstukken ter sprake, omdat het antwoord hierop voor een zeer groot deel afhangt van de beschikbaarheid van data en de kwaliteit van deze data.

\subsection{Scholingsbeleid}

Zoals in de inleiding al is gesteld, kan scholing een manier zijn om knelpunten op de arbeidsmarkt op te lossen. Diverse studies hebben laten zien dat er de komende tijd knelpunten zullen op gaan treden. Ook is al een aantal malen een poging gedaan om aan te geven in hoeverre deze opgelost zouden kunnen worden. De uitkomsten van dergelijke pogingen kunnen gevonden worden in Borghans e.a. (1998a) en De Grip, Jacobs en Vlasblom (1999a). De methode die in deze studies gebruikt werd, was het bepalen van de knelpunten per opleidingstype om vervolgens van de niet-participerende groepen op de arbeidsmarkt na te gaan in hoeverre deze beschikken over de desbetreffende opleiding. Borghans e.a. hebben daarnaast ook indicatief bepaald hoeveel om- en bijscholing er maximaal plaats zou kunnen vinden om de tekorten op te lossen. Beide genoemde studies baseren zich echter op nettostromen. Het nadeel daarvan is dat heel moeilijk aan te geven is welke groepen met scholing benaderd zouden moeten worden om de rendementen zo hoog mogelijk te maken.

Een ander bezwaar wordt genoemd in De Grip e.a. (1999a). De huidige prognosemethodiek resulteert in knelpunten naar opleidingstype, maar niet naar beroep. Het is op die manier heel moeilijk na te gaan aan welke vaardigheden er een tekort ontstaat. Bepaalde beroepen stellen meer eisen dan alleen een relevante opleiding; ook ervaring kan van groot belang zijn om een bepaald beroep uit te kunnen oefenen. Een tekort aan economen kan zich manifesteren bij het beroep van accountant, maar ook bij het beroep van docent economie op een HEAO. Afhankelijk van de vraag bij welk beroep het tekort zich voordoet, zal de benodigde scholingsinspanning verschillen. In het eerste geval zal het waarschijnlijk weinig effect hebben om werkloze historici tot econoom om te scholen, en zal men de doorstroom op de arbeidsmarkt moeten bevorderen, in het tweede geval zal de omscholing van werkloze historici waarschijnlijk heel effectief kunnen zijn. 
Samenvattend is het voor het scholingsbeleid dus noodzakelijk om te weten bij welke beroepen de tekorten zullen ontstaan. Daarnaast zal er voor deze beroepen duidelijk moeten zijn wie er 'door de markt' als relevant arbeidsaanbod gezien worden. Dit kan gebeuren door bijvoorbeeld na te gaan welke opleidingen er voor de diverse beroepen noodzakelijk zijn, en in hoeverre er aanvullende eisen gesteld worden (zoals bijvoorbeeld ervaring). Op die manier is het mogelijk om op basis van de voor dat beroep gewenste vaardigheden na te gaan welke werkende of werkzoekende de minste om- of bijscholing nodig heeft om het desbetreffende beroep adequaat uit te kunnen oefenen. De scholingsmaatregel kan zich dan vervolgens concentreren op deze groep, en op die manier veel gerichter ingezet worden dan mogelijk is op basis van prognoses naar opleiding.

Op grond van het bovenstaande is de informatiebehoefte vanuit een scholingsperspectief samen vatten in de volgende drie vragen:

- bij welke beroepen doet zich een knelpunt in de personeelsvoorziening voor op de korte termijn?

- welke werkenden of werkzoekenden kunnen bij- of omgeschoold worden zodat zij in die beroepen kunnen instromen?

- welke scholing is er voor deze groepen noodzakelijk?

Het antwoord op deze drie vragen moet het mogelijk maken het scholingsbeleid in te zetten tot een adequaat middel om de knelpunten te voorkomen of te verminderen.

\subsection{Bemiddelingsbeleid}

Korte-termijn arbeidsmarktprognoses kunnen in principe ook een waardevolle rol vervullen voor het beleid ten aanzien van de arbeidsmarktbemiddeling. De informatie over de discrepanties kan gezien worden als een indicatie waar bemiddeling noodzakelijk is, en waar de 'match' tussen vraag en aanbod op de arbeidsmarkt blijkbaar voldoende is. Er kan hierbij een tweetal perspectieven worden ingenomen. Ten eerste dat van de werkgevers, ten tweede dat van de werkzoekenden. Beide perspectieven vallen voor een deel samen, maar overlappen elkaar niet geheel.

Vanuit een werkgeversperspectief gaat het voornamelijk om de vraag bij welke beroepen er een tekort zal ontstaan gegeven de huidige verwachte ontwikkelingen. Zodra het duidelijk is bij welke beroepen de tekorten zich zullen voordoen, kan besloten worden om deze beroepen in de bemiddeling meer aandacht te geven. Hiervoor is het noodzakelijk om te weten wie er momenteel in deze beroepen werkzaam zijn, en wat de achtergrond van deze mensen is. Werkzoekenden die over deze (of een vergelijkbare) achtergrond beschikken kunnen dan bemiddeld worden naar dit beroep. Als het perspectief van de werkzoekenden tot uitgangspunt genomen wordt, kan nagegaan worden welk 'type' werkzoekende makkelijk een baan vindt, en welk 'type' werkzoekende altijd 'achter aan de rij' staat. Door na te gaan welke kenmerken deze beide groepen hebben, en dat te relateren aan de kenmerken die de verschillende beroepen vereisen, wordt duidelijk in welke beroepen beide groepen het best tot hun recht kunnen komen. Het bemiddelingsbeleid kan zich dan veel gerichter bezig houden met de groepen die zonder hulp moeilijk aan een baan kunnen komen. 
Het werkgevers- en werkzoekendenperspectief kunnen elkaar aanvullen: als het mogelijk is om de instroom op de arbeidsmarkt of de doorstroming zodanig te beïnvloeden dat de instroom van de 'zwakke groepen' leidt tot een vermindering van de knelpunten, vallen ze samen. Het is echter ook mogelijk dat de beide perspectieven niet samenvallen. In dat geval leidt de instroom in een beroep waar een tekort is, alleen tot een verplaatsing van een tekort naar een ander beroep, zonder dat de arbeidsmarktfrictie c.q. het totale (macro)tekort afneemt. Ook is het mogelijk dat extra instroom uit een 'zwakke groep' leidt tot verminderde instroom uit een andere groep omdat hetzelfde aantal banen verdeeld wordt over een groter aantal werkzoekenden. Dit doet zich voor als de extra instroom gerealiseerd wordt op plekken waar eigenlijk al voldoende aanbod was. De nieuwe instroom verdringt dan de oude, zodat het probleem van werkloosheid verplaatst wordt van de ene naar de andere werkzoekende.

Op grond van het bovenstaande is de informatiebehoefte vanuit een bemiddelingsperspectief samen vatten in de volgende drie vragen:

- bij welke beroepen doet zich op de korte termijn een knelpunt in de personeelsvoorziening voor?

- welke werkzoekenden kunnen ingezet worden in deze beroepen?

- zijn deze mensen beschikbaar en bereikbaar?

De laatste vraag valt eigenlijk al buiten de reikwijdte van het prognosemodel. Het prognosemodel kan iets zeggen over de omvang van de diverse groepen, maar de beschikbaarheid en de bereikbaarheid van mensen hangt af van andere factoren dan alleen opleiding en beroep.

\subsection{Loopbaanoriëntatie}

De twee voorgaande paragrafen zijn ingegaan op de informatiebehoefte van de werkgevers en de beleidsmakers. Maar ook voor de werkzoekenden of de werkenden zelf is informatie over de op korte termijn verwachte knelpunten op de arbeidsmarkt van belang. Op een andere manier gepresenteerd is de informatie belangrijk voor de voorlichting gericht op de loopbaanoriëntatie van mensen die zich reeds op de arbeidsmarkt bevinden.

De informatie ten behoeve van de loopbaanoriëntatie zal zich voornamelijk richten op de vraag waar er op korte en langere termijn goede perspectieven verwacht worden, en in hoeverre het voor de individuele werkzoekende of werkende mogelijk is in die functies terecht te komen. Daarnaast kan ook gedacht worden aan meer algemene informatie over het ontwikkelen van een loopbaan. Mensen doorlopen een bepaald traject op de arbeidsmarkt na afloop van hun initiële opleiding. De vraag is of het mogelijk is om hierbij aan te geven hoe deze trajecten zich ontwikkelen, los van de arbeidsmarktomstandigheden. Met andere woorden: voor de voorlichting over de loopbaan is het voornamelijk van belang om de nadruk te leggen op de mogelijke baan-baanmobiliteit, en in hoeverre men de overgang naar een andere beroep kan vergemakkelijken door zich om- of bij te scholen.

Samengevat is er voor de loopbaanvoorlichting de volgende informatie relevant: 
- waar bevinden zich de verwachte knelpunten in de personeelsvoorziening, en dus de perspectiefrijke beroepen?

- wat zijn de 'normale' overgangen die men tijdens zijn loopbaan maakt?

- volgens welke trajecten is het mogelijk om in bepaalde beroepen terecht te komen (gegeven de individuele kenmerken)?

Deze drie vragen hangen in zeer sterke mate samen met de informatiebehoefte die in de vorige twee paragrafen beschreven is. Eigenlijk vormen de informatiebehoefte van de werkgever en werknemer twee kanten van dezelfde medaille.

\subsection{Samenvatting en conclusie}

In de voorgaande drie paragrafen is kort uiteengezet waaruit de informatiebehoefte voor een kortetermijnmodel zou kunnen bestaan. Daaruit blijkt dat er weliswaar een aantal gebruiksdoelen kan worden onderscheiden, maar dat de feitelijke informatie voor deze doelen voor een deel samenvalt. Er moet dus een onderscheid aangebracht worden tussen de feitelijke informatiebehoefte, en de manier waarop deze informatie gepresenteerd wordt.

De onderscheiden gebruiksdoelen zijn het scholingsbeleid, het bemiddelingsbeleid, en de loopbaanvoorlichting. In de voorgaande paragrafen zijn de afzonderlijke informatiebehoeften beschreven. De totale informatiebehoefte laat zich als volgt samenvatten:

- bij welke opleidingen en beroepen doet zich op de korte termijn een knelpunt voor in de personeelsvoorziening?

- wat zijn de 'normale' overgangen die men tijdens zijn loopbaan maakt?

- volgens welke trajecten is het (gegeven iemands individuele kenmerken) mogelijk om in bepaalde beroepen terecht te komen?

- welke werkenden en/of werkzoekenden kunnen direct ingezet worden in de beroepen waar knelpunten worden verwacht?

- welke werkenden of werkzoekenden kunnen bij- of omgeschoold worden zodat zij in de beroepen waar knelpunten worden verwacht kunnen instromen?

De informatiebehoefte zoals hier is geschetst, maakt het moeilijk om de methodiek toe te passen die ten grondslag ligt aan de middellangetermijnprognoses. Deze methodiek is namelijk gebaseerd op nettostromen, terwijl het merendeel van de vragen die hierboven zijn gesteld, betrekking heeft op brutostromen. Een model voor de brutostromen maakt het mogelijk expliciet rekening te houden met de baan-baanmobiliteit van werkenden en de brutoarbeidsmarktuitstroom. Het moge duidelijk zijn dat een dergelijk model zeer hoge eisen stelt aan de data, waardoor het moeilijk kan zijn om een, voor de gebruiksdoelen noodzakelijk, laag aggregatieniveau te bereiken.

Bij de presentatie van de informatie moet rekening gehouden worden met het onderhavige gebruiksdoel. Dit geldt voor de wijze waarop de informatie gepresenteerd wordt, en dan met name met betrekking tot het perspectief dat hierbij ingenomen wordt. Het geldt echter ook voor de prognosetermijn die gehanteerd wordt. De prognoses ten behoeve van het bemidde- 
lingsbeleid zullen betrekking moeten hebben op het kalenderjaar waarin ze worden gepubliceerd. Ten aanzien van de scholingsplanning is er waarschijnlijk met name behoefte aan arbeidsmarktprognoses die langer vooruit kijken, omdat niet de huidige situatie van belang is, maar de verwachte situatie op het moment dat de opleiding afgerond is. Dit vraagt overigens wel om een afweging tussen de korte-termijn- en de middellangetermijnprognoses. Het is namelijk de vraag in hoeverre het kortetermijnrendement c.q. de arbeidsmarktperspectieven direct na afloop van de cursus richtinggevend moet zijn, wanneer dit afwijkt van het verwachte rendement op de middellange termijn.

\section{Beschrijving van het kortetermijnmodel}

\subsection{Inleiding}

Het model dat gebruikt gaat worden voor de kortetermijnprognoses is gebaseerd op brutostromen op de arbeidsmarkt. Deze keus is gemaakt omdat met het middellangetermijnmodel niet in de informatiebehoefte kan worden voorzien. Een brutostromenmodel wijkt qua opzet of van het middellangetermijnmodel, en sluit veel beter aan bij de informatiebehoefte. Er kunnen verschillende soorten stromen op de arbeidsmarkt onderscheiden worden: er kan gekeken worden naar stromen van mensen die van arbeidsmarktpositie veranderen, of van opleidingstype, beroep, etc. In dit hoofdstuk zal een model uiteengezet worden dat dergelijke stromen beschrijft. Hierbij wordt ingegaan op de structuur van het model, de specificatie van de afzonderlijke 'componenten' en de databehoefte die dit model met zich meebrengt. De structuur laat zich beschrijven in een drietal componenten. Het eerste is een component dat de mobiliteit van werkenden verklaart. Hierbij wordt zowel de mobiliteit naar een andere baan of ander beroep bedoeld, als de uitstroom van de arbeidsmarkt. Daarnaast is er een tweetal componenten die de instroom op de arbeidsmarkt beschrijven: de arbeidsmarktinstroom van de schoolverlaters, en de instroom van niet-participerenden. Bij de instroom van de schoolverlaters kan in principe ook gedacht worden aan het modelleren van de mogelijkheid van doorstuderen. In paragraaf 3.2 wordt eerst ingegaan op het stromenmodel, waarna in paragraaf 3.3 aangegeven zal worden hoe de uitkomsten van dit model gebruikt zullen worden om prognoses op macroniveau te maken. Paragraaf 3.4 gaat tenslotte kort in op de relatie met het middellangetermijnmodel.

\subsection{De stromen op de arbeidsmarkt}

Als het gaat om het bestuderen van de mobiliteit, lijkt het - mede gezien de gebruiksdoelen - voor de hand te liggen om de baan en, daarmee samenhangend, het beroep als uitgangspunt te nemen. Het is namelijk eenvoudiger om gevraagde en aangeboden kwalificaties op beroepsniveau te specificeren, dan aan de hand van de gevraagde opleidingen te onderzoeken welke vaardigheden er feitelijk verlangd worden (Zie De Grip e.a., 1999a). Ook blijkt dat de meeste actoren op de markt denken in termen van banen, vacatures en werkzoekenden. Werkzoekenden zijn op zoek naar een baan, werkgevers op zoek naar iemand die een vacature kan vervullen. Voor de gebruikers is het dus ook een voordeel om het model - zo mogelijk - te specificeren in termen van deze grootheden. Er lijkt dus zowel 
een inhoudelijk als een praktisch voordeel te zijn om aansluiting te zoeken bij de specificatie op beroepsniveau. Uiteraard moet wel aandacht geschonken worden aan de mogelijkheden om de brutostromen te koppelen aan de uitkomsten van het nettostromen-model.

Omdat de informatiebehoefte zich toespitst op baan- en/of beroepsmobiliteit lijkt het voor de hand te liggen om de feitelijke arbeidsmarktpositie als uitgangspunt te nemen. Deze keus sluit aan bij de keus die gemaakt is in de eerdere ROA-rapporten Stromen op de arbeidsmarkt in de Zorgsector (Borghans e.a., 1998a) en Toekomstverkenning arbeidsmarkt apothekersassistenten in de openbare apotheek (De Grip en Vlasblom, 1999b). In deze beide rapporten is er voor gekozen om iemand mee te tellen in een stroom als zijn arbeidsmarktpositie verandert. Hierbij wordt gesproken van een verandering van arbeidsmarktpositie als er sprake is van een overgang van school naar werk of omgekeerd, van niet-participerend naar participerend of omgekeerd, maar ook als er sprake is van het veranderen van beroep en/of werkgever. In beide genoemde rapporten diende de ontwikkeling binnen een sector als uitgangspunt. Omdat in dit model de totale arbeidsmarkt als uitgangspunt wordt genomen, moeten ook de stromen tussen niet-participerend en school in de analyses opgenomen worden, juist omdat voor niet-participerenden de weg terug naar de arbeidsmarkt (vaak) loopt via een scholingstraject. Stromen tussen regio's kunnen ook van belang zijn in bepaalde analyses. Regionale verschillen in arbeidsmarktkansen zijn soms ook een aanleiding om van baan en regio te veranderen. (Zie Borghans e.a., 1998a). In principe zouden deze stromen betrokken moeten worden bij het maken van de prognoses, omdat een ongelijke regionale spreiding van vraag en aanbod kan leiden tot knelpunten die op een geaggregeerd, landelijk niveau niet lijken voor te komen. Dit zou vooral bij de lagere opleidingsniveaus een probleem kunnen vormen, daar deze doorgaans een lagere regionale mobiliteit vertonen (zie bijvoorbeeld Windmeijer, 1992).

Afgezien van de regionale mobiliteit kan de arbeidsmarkt beschreven worden met een stromendiagram zoals weergegeven in figuur 1 . Hierbij wordt de arbeidsmarkt als een min of meer gesloten systeem beschouwd: de enige toegang is via de demografisch bepaalde instroom van het onderwijs. De enige uitgang is de status 'exit', die weergeeft dat iemand de arbeidsmarkt definitief verlaten heeft. Deze 'exit' is ook voor een groot deel demografisch bepaald door pensionering of overlijden, maar kent ook een niet-demografische component, bijvoorbeeld emigratie of volledige arbeidsongeschiktheid. Binnen het systeem onderscheiden we drie groepen: de werkenden, de scholieren en de niet-participerenden. Onder deze laatste groep rekenen we hier zowel de werklozen als diegenen die zich niet (actief) aanbieden op de arbeidsmarkt.

Binnen dit arbeidsmarktmodel worden twee ontwikkelingen exogeen bepaald. Ten eerste is dat het aantal scholieren. De omvang van de groep scholieren wordt voornamelijk demografisch verklaard, en niet binnen het model. Het model beperkt zich tot uitspraken over de plekken waar deze scholieren instromen op de arbeidsmarkt. Ook de ontwikkeling van de werkgelegenheid wordt niet door het model verklaard. De omvang van de werkgelegenheid aan het eind van de prognoseperiode wordt als een gegeven beschouwd: de stromen op de markt verklaren niet hoe de omvang van de werkgelegenheid zich ontwikkelt. De overige ontwikkelingen worden wel binnen het model verklaard. 
Figuur 1

Een stroomschema van de arbeidsmarkt

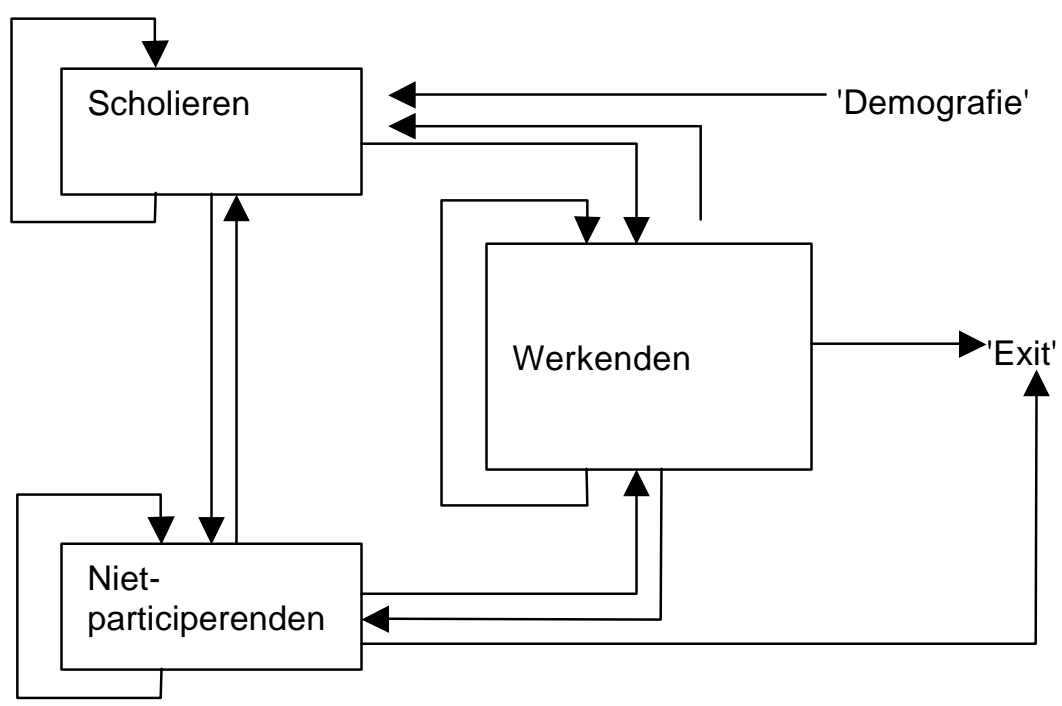

\section{De werkenden}

Voor de groep werkenden is een aantal stromen op de arbeidsmarkt relevant. De werkenden 'stromen in' vanuit de groep scholieren en vanuit de groep niet-participerenden. De uitstroom vindt plaats naar de studerenden, de niet-participerenden en de definitieve 'exit' (pensioen). Ten aanzien van de in- en uitstroom zou eigenlijk ook aandacht geschonken moeten worden aan mensen die in deeltijd werken en/of studeren. In de nettostromenmethodiek van met middellangetermijnmodel is hier een oplossing voor gevonden door de niveauverhogende scholing te 'compenseren' met een bijbehorende uitbreidingsvraag voor het hogere opleidingstype. Een brutostromenmodel zal hier een andere oplossing voor moeten vinden, desnoods bestaande uit het invoeren van een extra 'tussencategorie' tussen leren en werken. Het invoeren van een dergelijke categorie heeft misschien een voordeel ten aanzien van de gebruiksdoelen van het model: er kan dan namelijk een derde instroomcategorie op de arbeidsmarkt onderscheiden worden. Deze categorie is die van de mensen die naast hun werk een aanvullende cursus of opleiding gevolgd hebben. Als er wordt geanalyseerd wat de concurrentieverhoudingen zijn tussen de diverse groepen kan een explicitering van deze aparte groep misschien nuttig zijn. Dit zou echter op basis van empirische uitkomsten overwogen moeten worden. Daarnaast is er binnen de groep werkenden sprake van baanbaanmobiliteit. Deze baan-baanmobiliteit kan gepaard gaan met beroepsmobiliteit of regionale mobiliteit, maar dat hoeft niet het geval te zijn: je kunt van baan veranderen zonder van beroep of regio te veranderen. Andersom kan nooit: een verandering van beroep is niet mogelijk zonder verandering van baan. Alleen hoeft deze mobiliteit weer niet gepaard te gaan met een verandering van werkgever. 
Het model moet een beschrijving geven van de mobiliteit die optreedt. Er moet daarbij - zo mogelijk - onderscheid gemaakt worden tussen enerzijds de mogelijkheden die mensen hebben om mobiel te worden en anderzijds de behoefte en bereidheid die mensen hebben tot mobiliteit. De mogelijkheden tot mobiliteit vinden hun oorsprong in de vraag naar arbeid, en meer specifiek geformuleerd, het bestaan van vacatures op de arbeidsmarkt. Verschillen in de mogelijkheden voor diverse mensen om mobiel te worden kunnen dan beschreven worden door de vacatures onder te verdelen naar richting en niveau zoals ook gedaan is in Willems e.a. (1997). De vraag naar arbeid (de vacatures) is dus ook de 'motor' van het totale systeem, zonder deze zouden de meeste stromen tot nul reduceren. De vraag naar arbeid ontstaat uit twee bronnen, allereerst is hij het gevolg van veranderingen in de omvang van de werkgelegenheid. Er is dan sprake van een nieuwe werkplek als gevolg van het feit dat de werkgelegenheid toeneemt. Er wordt hierbij wel van uitgegaan dat de totale hoeveelheid arbeid die gevraagd wordt exogeen bepaald wordt: de totale vraag naar arbeid staat dus los van het totale aanbod. Daarnaast kunnen vacatures het gevolg zijn van het feit dat werknemers naar elders vertrekken, en een open plaats achterlaten die opnieuw opgevuld dient te worden. Vertrek van een werknemer kan zoals in het schema aangegeven staat meerdere oorzaken hebben: hij of zij kan gedwongen zijn de arbeidsmarkt te verlaten (overlijden, pensioen), of stoppen met werken vanwege andere activiteiten (bijvoorbeeld vrouwen die stoppen met werken vanwege de verzorging van de eigen kinderen). Het is in principe ook mogelijk dat werknemers terugkeren naar een voltijds opleiding, alhoewel dit niet zo vaak zal voorkomen.

Zodra er ergens een vacature ontstaat, bestaat er in principe de mogelijkheid voor herintreders of schoolverlaters om toe te treden tot de groep werkenden. Een vacature hoeft niet per definitie door een schoolverlater opgevuld te worden. Een werkgever kan redenen hebben om een herintreder of een werkende te willen hebben voor de vervulling van de betreffende vacature. Dit heeft mobiliteit binnen de groep werkenden tot gevolg: er is ergens een open plek die vervuld wordt door iemand die op zijn beurt ook weer een open plek achterlaat: er ontstaat op die manier een vacatureketen. Een dergelijke vacatureketen wordt pas 'gesloten', als er vanuit de scholieren of de niet-participerenden iemand de vacature vervult. Hoe korter de vacatureketens binnen een bepaald beroep, des groter blijkbaar de voorkeur van werkgevers voor schoolverlaters of herintreders in een dergelijk beroep. Als er sprake is van lange vacatureketens, geven werkgevers blijkbaar de voorkeur aan mensen met werkervaring, en nemen ze slechts sporadisch een schoolverlater of herintreder aan. De lengte van de vacatureketen kan dus gezien worden als een maatstaf voor de mogelijkheden die beide groepen op de arbeidsmarkt hebben.

Bij de modellering van de mobiliteit op de arbeidsmarkt moet waarschijnlijk ook aandacht besteed worden aan de vraag in hoeverre er sprake geweest is van expliciete vacatures. Dit is vooral van belang op de 'interne arbeidsmarkt' binnen een bedrijf. Een ander punt dat aandacht behoeft bij de modellering is de vraag in hoeverre er betrouwbare gegevens beschikbaar zijn omtrent de baan-baanmobiliteit. 
De tweede groep die binnen het model onderscheiden wordt, is die van de scholieren, of iets ruimer geformuleerd, iedereen die bezig is met een voltijds opleiding. Dat kunnen scholieren in het initieel onderwijs zijn, maar ook mensen die al gewerkt hebben, of niet-participerenden die opnieuw een opleiding gevolgd hebben om daarna makkelijker terug te kunnen keren op de arbeidsmarkt. Ten aanzien van de scholieren is een aantal stromen relevant. Allereerst de onderwijsinstroom: deze bestaat uit de door de demografische ontwikkelingen bepaalde instroom en het aantal werkenden en niet-participerenden dat een opleiding gaat volgen. Vanwege de leerplicht en de demografische opbouw van de bevolking ligt de instroom in het initieel onderwijs vast gegeven de bevolkingsontwikkeling. De schoolkeuze die men na de basisschool maakt, zal voor een zeer groot deel gebaseerd zijn op iemands capaciteiten. De keuze voor het niveau is daarmee dus ook voor een groot deel exogeen bepaald. Echter, de initiële keuze die men maakt wat betreft de opleidingsrichting zal voor een deel gebaseerd zijn op endogene factoren. Behalve individuele voorkeuren (die exogeen bepaald zijn), zullen 'studiekiezers' zich laten leiden door huidige of verwachte arbeidsmarktperspectieven voor de verschillende opleidingen. Borghans e.a. (1996) laten zien dat het hier gaat om zowel baankansen als verwacht inkomen. Zij laten zien dat in 1984 in het lager technisch onderwijs ongeveer $10 \%$ van de studenten de keus voor een bepaalde richting laat beïnvloeden. De instroom vanuit de groep werkenden en niet-participerenden wordt waarschijnlijk voor een groot deel bepaald door de situatie op de arbeidsmarkt: als deze situatie slecht is, zal een toenemend deel van de werkenden besluiten om door een aanvullende opleiding hun kansen te vergroten.

Daarnaast is de onderwijsuitstroom van belang: als mensen een opleiding afgerond hebben zoeken zij een baan op de arbeidsmarkt. Als dat lukt, dan stromen zij uit naar de groep werkenden. Lukt dat niet, of wordt er zelfs helemaal niet gezocht, dan stromen zij uit naar de groep niet-participerenden. Een laatste stroom is de 'doorstroom' van opleiding naar opleiding. Hiervan is sprake als men na het afronden van een opleiding aansluitend een volgende opleiding gaat volgen. Zodra men een opleiding afgerond heeft, zal men voor de keuze staan een volgende opleiding te gaan volgen of de arbeidsmarkt te betreden. Voor een deel ligt deze opeenvolging van opleidingen besloten in de aard van de opleiding, na het VWO zal een zeer groot deel van de afstudeerders een WO of HBO opleiding gaan volgen. Voor een deel zal de afweging een vervolgopleiding te gaan volgen beïnvloed worden door de baankansen op dat moment. Vervolgopleidingen zijn in zekere zin een manier om de toetreding tot de arbeidsmarkt te vertragen. Zeker als men op het moment waarop men de opleiding afrondt, ervaart dat de arbeidsmarktpositie minder goed is dan verwacht, zal de animo om een vervolgopleiding te gaan volgen groot zijn; in dat geval wordt het volgen van een opleiding een alternatief voor werkloosheid. Daarnaast zal het percentage van de mensen dat een vervolgopleiding gaat volgen ook beïnvloed worden door het aantal 'spijtoptanten' dat tijdens de studie ontdekt heeft dat de opleiding toch niet datgene biedt wat ze er van verwacht hadden. 
De derde relevante groep is die van de niet-participerenden. Deze groep omvat hier enerzijds de werkzoekenden zonder baan (de werklozen), en anderzijds degenen die behoren tot de potentiële beroepsbevolking, maar op dit moment niet werkzoekend zijn (de 'echte' niet-participerenden). De omvang van deze groep is relatief groot, en functioneert voor de arbeidsmarkt vaak als een soort buffer. Wanneer er te weinig werk is, verdwijnt een deel van de werkenden (al dan niet vrijwillig) naar deze groep. Aan de andere kant zal men zodra er te weinig schoolverlaters zijn om de beschikbare open plekken op de arbeidsmarkt te vullen, arbeidskrachten uit deze groep moeten werven.

Instroom in de groep niet-participerenden kan plaatsvinden vanuit de schoolverlaters, en vanuit de werkenden (evt. ook door migratie, dus demografisch bepaald). Er kan hierbij sprake zijn van economische, arbeidsmarkt gerelateerde aspecten: schoolverlaters met een opleiding die weinig kans biedt op een baan lopen een groot risico om niet-participerend (werkloos) te worden. Ditzelfde geldt voor werknemers die een zwakke positie op de arbeidsmarkt innemen (bijvoorbeeld laaggeschoolden in krimpsectoren). In beide gevallen betreft het mensen die om wat voor reden dan ook geen baan willen, of er geen kunnen vinden, of hun baan zijn kwijtgeraakt. De instroom in de groep niet-participerenden is vaak ook bepaald door persoonlijke omstandigheden: een aanzienlijke groep vrouwen stopt (al dan niet tijdelijk) met betaald werk zodra zij kinderen krijgen. Ook langdurige ziekte kan een periode van non-participatie tot gevolg hebben.

Niet-participerenden kunnen naar drie bestemmingen uitstromen: ze kunnen besluiten een opleiding te gaan volgen, ze kunnen er in slagen een baan te vinden, of ze kunnen door wat voor reden dan ook de arbeidsmarkt definitief verlaten. Ook de uitstroom uit de groep nietparticiperenden (voornamelijk herintreders op de arbeidsmarkt) is vaak bepaald door redenen van persoonlijke aard: zoals veel vrouwen stoppen met werken vanwege de opvoeding van hun kinderen, zo hebben er ook veel de wens tot herintrede wanneer de kinderen ouder worden. Aan de andere kant kan de uitstroomkans uit de groep nietparticiperenden gerelateerd worden aan arbeidsmarkt gerelateerde factoren: een tekort aan schoolverlaters kan de kans op werk voor werklozen vergroten. Ook het opleven van de vraag naar bepaalde kwalificaties waar langere tijd geen vraag naar geweest is kan de kans op herintrede van niet-participerenden vergroten. Zo is op dit moment de vraag naar leraren zo groot dat men gaat werven onder de potentiële herintreders. Niet-participerenden kunnen ook besluiten om - al dan niet voltijds - een opleiding te gaan volgen om hun arbeidsmarktkansen te vergroten: tal van cursussen (o.a. geïnitieerd door Arbeidsvoorziening) zijn gericht op het opfrissen van vakkennis van herintredende vrouwen, het omscholen van werkzoekenden etc ${ }^{1}$. Voor zover het gaat om stromen vanuit de groep niet-participerenden naar de definitieve 'exit' (pensioen), worden deze voor een groot deel bepaald door exogene

1. Door aan een dergelijke opleiding te beginnen worden de niet-participerenden studerenden, en tellen ze in dit model ook als uitstroom van niet-participerenden nog voordat ze daadwerkelijk een baan gevonden hebben. 
factoren: leeftijd is vanwege de pensioenregels een duidelijk bepalende factor voor het verlaten van de arbeidsmarkt.

Ook binnen de groep niet-participerenden kan er sprake zijn van doorstroom: namelijk tussen de groep niet-participerenden die wel zoekt naar een baan (de werklozen), en de groep niet-participerenden die niet zoekt naar een baan of andersom. Deze doorstroom is voor een groot deel bepaald door de arbeidsmarktomstandigheden: hoe langer men werkloos is, hoe kleiner de binding met de arbeidsmarkt wordt, en hoe groter de kans dat men zich als niet-participerend gaat beschouwen. Aan de andere kant: als de kansen op de arbeidsmarkt groter worden, kan dit niet-actief zoekenden er toe overhalen zich weer actief als werkzoekend aan te bieden.

\subsection{Het prognosemodel}

Het model dat de bewegingen zoals die in figuur 1 geïllustreerd worden verklaart, ligt ten grondslag aan het model dat gehanteerd wordt voor het opstellen van de arbeidsmarktprognoses. De structuur van het prognosemodel wordt weergegeven in figuur 2. Binnen dit prognosemodel worden de bevindingen uit het micro-economisch georiënteerde stromenmodel gebruikt om macroarbeidsmarktprognoses te maken. Zoals in de vorige paragraaf is aangegeven, zijn er twee zaken die in het brutostromenmodel exogeen verondersteld worden. Dat zijn de verwachte omvang van de werkgelegenheid en de demografisch bepaalde instroom in de groep scholieren.

Binnen het prognosemodel zal voor de verwachte omvang van de werkgelegenheid gebruik gemaakt worden van het uitbreidingsvraagmodel dat voor de middellangetermijnprognoses is ontwikkeld. De uitbreidingsvraag geeft de ontwikkeling weer van de werkgelegenheid in een bepaalde beroepsgroep of voor een bepaald opleidingstype. In termen van figuur 1 geeft de uitbreidingsvraag dus aan wat de door werkgevers gewenste omvang van de groep werkenden is. De prognoses van de uitbreidingsvraag zijn gebaseerd op de werkgelegenheidsprognoses voor bedrijfssectoren van het Centraal Planbureau. Net zoals bij de middellangetermijnprognoses worden ook de kortetermijnprognoses aangepast voor verschuivingen in de beroepenstructuur binnen de onderscheiden bedrijfssectoren. Hierdoor kan er rekening gehouden worden met het feit dat binnen een bedrijfssector bepaalde beroepsgroepen zich sneller ontwikkelen dan andere. Dit zijn echter bij uitstek ontwikkelingen die plaatsvinden over een langere termijn, het effect hiervan op de korte termijn zal dus heel klein zijn. Ditzelfde geldt voor het optreden van verschuivingen in de opleidingenstructuur van beroepsgroepen.

Naast uitbreidingsvraag is er op de arbeidsmarkt sprake van uitstroom. Deze uitstroom wordt bepaald aan de hand van de bevindingen van het brutostromenmodel. De totale arbeidsmarktuitstroom wordt bepaald door iedereen die zijn baan verlaat als uitstroom te tellen. Dit is dus de som van een viertal stromen:

- de uitstroom naar de groep scholieren;

- de uitstroom naar de groep niet-participerenden (o.a. tijdelijke terugtreding van de arbeidsmarkt); 
- de groep die de arbeidsmarkt verlaat door - al dan niet vervroegde - pensionering, arbeidsongeschiktheid;

- de groep van mensen die hun baan verlaat om elders in een nieuwe baan te beginnen.

Deze uitstroom zal leiden tot vraag naar nieuw personeel, tenzij de uitstroom gebruikt wordt om een werkgelegenheidskrimp te effectueren. Omdat de uitstroom bekend is per opleidingssector en beroep, kan door het optellen van de totale uitstroom en de uitbreidingsvraag de totale vraag per opleidingssector of beroepssector bepaald worden.

Tegenover de totale vraag naar arbeidskrachten staat het (verwachte) aanbod van arbeidskrachten. Er is binnen het model sprake van drie groepen aanbieders: de doorstromers, de schoolverlaters en de niet-participerenden. Allereerst bestaat het aanbod uit de mensen die doorstromen naar een andere baan. Deze mensen verlaten een baan, maar stromen op een andere plaats direct weer in. De plaats (beroepssector) waar zij instromen wordt bepaald op basis van het brutostromenmodel. De keus voor de baan waar zij zich aanbieden hangt af van hun persoonlijke kenmerken, o.a. opleiding en leeftijd. Naast dit aanbod van doorstromers op de arbeidsmarkt is er ook sprake van aanbod van schoolverlaters uit het initieel en het niet-initieel onderwijs op de arbeidsmarkt. De instroom van de schoolverlaters zal (mede) worden gebaseerd op hetzelfde model dat voor de middellangetermijnprognoses gehanteerd wordt. De prognoses van de instroom van schoolverlaters op de arbeidsmarkt hebben, net zoals de meest recente uitgave van De arbeidsmarkt naar opleiding en beroep, als uitgangspunt de Referentieraming van het Ministerie van Onderwijs, Cultuur en Wetenschappen met betrekking tot de verwachte uitstroom uit het initiële onderwijs. Door het ROA zijn deze prognoses nader verbijzonderd en aangevuld met prognoses van de doorstroom naar het niet-reguliere onderwijs. De derde 'instroomcategorie' wordt gevormd door de verwachte instroom van herintreders (bestaande uit de instroom van werklozen die een baan gevonden hebben, en van niet-participerenden die weer gaan werken). De omvang van deze stromen, en de plaats waar zij zich aanbieden worden ook weer bepaald op basis van het brutostromenmodel.

Door de verwachte vraag- en aanbodstromen met elkaar te confronteren wordt een ex-ante indicatie verkregen van ontwikkelingen in het aantal werkenden per opleiding of beroep. Door deze verwachte ontwikkelingen te vergelijken met de uitbreidingsvraag, kan een indicatie verkregen worden van de knelpunten op de arbeidsmarkt die op zullen gaan treden. Deze indicator geeft aan welke vraag-aanboddiscrepantie er per opleidingstype (of beroep) te verwachten is. Deze indicator kan vanuit twee perspectieven geïnterpreteerd worden: vanuit het oogpunt van de werkzoekende en vanuit het oogpunt van de werkgevers. Als de verwachte groei van het aantal werkenden groter is dan de uitbreidingsvraag, zal er sprake zijn van een overschot aan werkenden, dus minder goede perspectieven voor werkzoekenden, maar geen knelpunten in de personeelsvoorziening. Als de verwachte groei van het aantal werkenden daarentegen lager is dan de uitbreidingsvraag, zal er sprake zijn van een tekort aan arbeidskrachten, dat wil zeggen: goede perspectieven voor werkzoekenden, maar ook knelpunten in de personeelsvoorziening voor de werkgevers. 
Figuur 2

Globale opzet van het prognosemodel

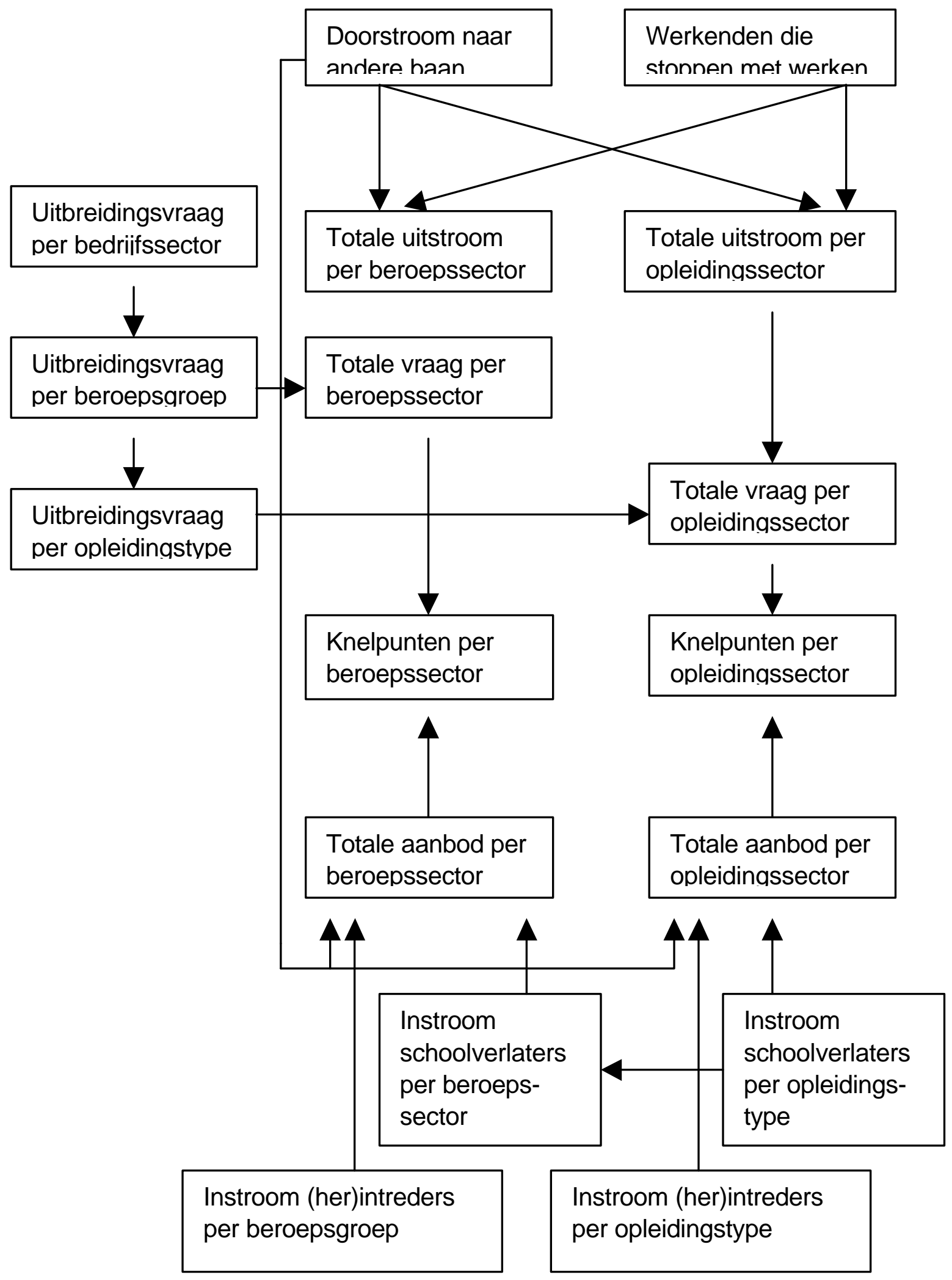




\subsection{De relatie met het middellangetermijnmodel}

Uit het voorgaande is gebleken dat tot op zekere hoogte de uitkomsten van het kortetermijnmodel en het middellangetermijnmodel vergelijkbaar zijn. Daar waar het de uitbreidingsvraag en de instroom van schoolverlaters betreft, is de prognosetermijn het enige verschil tussen beide modellen. Wat betreft de andere grootheden is er wel een duidelijk verschil.

Zo wordt in het nettostromenmodel de vervangingsvraag gedefinieerd als de uitstroom die leidt tot vraag naar nieuwkomers op de arbeidsmarkt. In het brutostromenmodel wordt totale uitstroom als vraag meegeteld. De Grip en Vlasblom (1999b) geven overigens aan dat met een brutostromenmodel een redelijke aansluiting met de nettostromen is te verwezenlijken. Door een goede saldering van de stromen is dus een relatie te leggen met de in de middellangetermijnprognoses van het ROA gebruikte concepten arbeidsmarktinstroom, uitbreidingsvraag, vervangingsvraag en dus ook met de baanopeningen (zie ROA, 1999a). In principe is de (netto)vervangingsvraag af te leiden uit de saldering van de diverse brutostromen: Bij benadering is de nettovervangingsvraag gelijk aan de totale uitstroom minus het aanbod van de baanwisselaars en de instroom van herintreders. Daarnaast moet ook een deel van de herintreders verdisconteerd worden, omdat in het nettostromenmodel de nettostroom naar de niet-participerenden al verdisconteerd is. Het aanbod vanuit de nietparticiperende dat er niet in geslaagd is een baan te vinden wordt echter niet verdisconteerd, daarvan wordt juist aangenomen dat deze mensen minder gewenst zijn dan de schoolverlaters. Deze expliciete informatie over de baanwisselaars en de (her)intrede uit de niet-participerenden vormt een van de grote verschillen met het middellangetermijnmodel dat uitsluitend uitgaat van aanbod van schoolverlaters en kortdurig werklozen. De arbeidsmarktinstroom van schoolverlaters is het totaal aantal schoolverlaters dat beschikbaar komt voor de arbeidsmarkt, waarbij geen uitspraak gedaan wordt over de vraag of zij werkloos worden of niet. Hier is er ook een verschil met het brutostromenmodel, omdat het laatste model in principe wel corrigeert voor het aantal schoolverlaters dat werkloos wordt. De schoolverlaters die al een plek op de arbeidsmarkt hadden voordat zij een opleiding gingen volgen tellen in beide modellen mee met de arbeidsmarktuitstroom voor hun oorspronkelijke opleidingstype, hun werkplek wordt gesaldeerd via de uitbreidings- en vervangingsvraag.

Er moet bij deze saldering wel een tweetal kanttekeningen geplaatst worden. Ten eerste is er voor het bepalen van knelpunten op de middellange termijn een vraagcomponent - de substitutievraag - die aangeeft in hoeverre vraag en aanbod zullen verschuiven als gevolg van optredende knelpunten. Deze component ontbreekt vooralsnog in het brutostromenmodel. De tweede kanttekening betreft het feit dat in het brutostromenmodel de omvang van de diverse stromen per jaar worden bepaald, terwijl het middellangetermijnmodel betrekking heeft op een periode van vijf jaar. Dit heeft tot gevolg dat bij sectoren die een hoge mobiliteit kennen er relatief grote verschillen kunnen optreden tussen beide modellen. Als werknemers in een bepaalde functie gemiddeld genomen ieder jaar van baan veranderen, telt dit in het nettostromenmodel een keer mee, terwijl in het brutostromenmodel deze plek over een periode van vijf jaar vijf keer meetelt. 
Opgemerkt moet worden dat zowel de vraag als het aanbod in het hier gehanteerde model ruimer gedefinieerd zijn dan in de middellangetermijnprognoses zoals die in De arbeidsmarkt naar opleiding en beroep gepresenteerd worden. Naar de kant van de werkzoekenden mogen ze dus ook ruimer geïnterpreteerd worden: het gaat nu niet meer om perspectieven voor alleen schoolverlaters, maar ook om perspectieven van werkzoekenden met een andere achtergrond. Door de andere methodiek zullen ook de uitkomsten per opleiding of beroep af kunnen wijken van de uitkomsten uit de middellangetermijnprognoses. Een tweede opmerking ten aanzien van de vergelijkbaarheid tussen de middellangetermijnprognoses en de kortetermijnprognoses betreft de indicator die knelpunten per beroep aangeeft. De hiervoor in dit werkdocument gehanteerde methodiek wijkt sterk af van de methodiek die in de meest recente uitgave van De arbeidsmarkt naar opleiding en beroep gehanteerd wordt. Momenteel door het ROA ook nader onderzocht hoe deze knelpunten beter in kaart gebracht kunnen worden. De knelpunten per beroep moeten dan ook als indicatief beschouwd worden.

In de middellangetermijnprognoses van het ROA wordt er altijd zeer nadrukkelijk op gewezen dat om te bepalen hoeveel mensen met een bepaalde achtergrond er nodig zijn, het niet juist is om naar het totaal aantal vacatures in een bepaalde periode te kijken. In dat geval wordt het aantal benodigde arbeidskrachten vanwege het optreden van vacatureketens immers sterk overschat, waarbij de overschatting groter is naarmate de lengte van deze vacatureketens groter is. Juist omdat de optredende brutostromen binnen het hier gepresenteerde model wel expliciet gemaakt kunnen worden, kan er nu een relatie gelegd worden tussen de baanopeningen, het aantal vacatures en de lengte van de vacatureketens.

\section{Empirische specificatie van het model}

\subsection{Inleiding}

In het voorafgaande hoofdstuk is een omschrijving gegeven van de structuur van het model, waarbij is aangegeven hoe de structuur van het model er uit zou moeten zien. Hierbij is echter geen aandacht geschonken aan de empirische specificatie van het model. In dit hoofdstuk zal worden uiteengezet hoe de empirische specificatie van het model er uit ziet, en in hoeverre er data voorhanden zijn om dit model mee te schatten. Er wordt daarbij uitgegaan van het Sociaal Economisch Panel (SEP). Voor de definitieve prognoses zal waar mogelijk - gebruik worden gemaakt van gegevens uit de schoolverlatersenquêtes en de EBB. In paragraaf 4.2 wordt ingegaan op de econometrische specificatie van het model, in paragraaf 4.3 op de beschikbare data en de schattingsresultaten. In paragraaf 4.4. zal ingegaan worden op de informatie die gegenereerd kan worden, en hoe met deze informatie in de in hoofdstuk 2 geschetste behoefte voorzien kan worden. Op verschillende plaatsen zal, indien nodig, aangegeven worden wat de relatie is met de bestaande prognoseprogramma's. 


\subsection{De econometrische specificatie}

Zoals in paragraaf 3.3 is aangegeven, wordt er eerst een brutostromenmodel gespecificeerd, dat vervolgens gebruikt wordt om macroprognoses te maken. De aanpak is daarbij als volgt. Op basis van de beschikbare microdata wordt een verklarend model geschat voor de individuele overgangskansen tussen de onderscheiden posities op de arbeidsmarkt. Deze kansen worden afhankelijk verondersteld van een aantal persoonlijke kenmerken zoals opleiding, leeftijd, en geslacht en de positie die men inneemt op of buiten de arbeidsmarkt. Door vervolgens op basis van geaggregeerde data na te gaan hoeveel mensen er over die kenmerken beschikken kan een indicatie verkregen worden van de omvang van de verwachte mobiliteit die op zal treden. Deze mobiliteit wordt namelijk afgeleid uit een vermenigvuldiging van het aantal individuen met bepaalde kenmerken en de overgangskansen die voor dat 'type' individu bepaald zijn. Het aggregeren van de diverse stromen levert de verwachte populatieontwikkeling op. Een dergelijk stromenmodel is ook gehanteerd in Borghans e.a. (1998a). In deze studie is het model gebruikt om scenario's door te rekenen over een termijn van een jaar. Het is daarbij gebleken dat het model stabiele uitkomsten geeft en dat de ontwikkelingen op de korte termijn er redelijk mee beschreven kunnen worden. Uit De Grip en Vlasblom (1999b) blijkt dat een langere voorspelhorizon moeilijker te realiseren is, omdat het voor het bepalen van de diverse mobiliteitskansen noodzakelijk is om de populatie aan het begin van iedere periode te construeren. Dit is in principe wel mogelijk, maar de te verwachten afrondfouten zijn vrij groot. Het lijkt dus dat het moeilijk is om met het huidige model voor een termijn verder dan 4 à 5 jaar vooruit een betrouwbare prognose van de populatieopbouw te verkrijgen.

Figuur 3

Een schematische weergave van het empirische stromenmodel

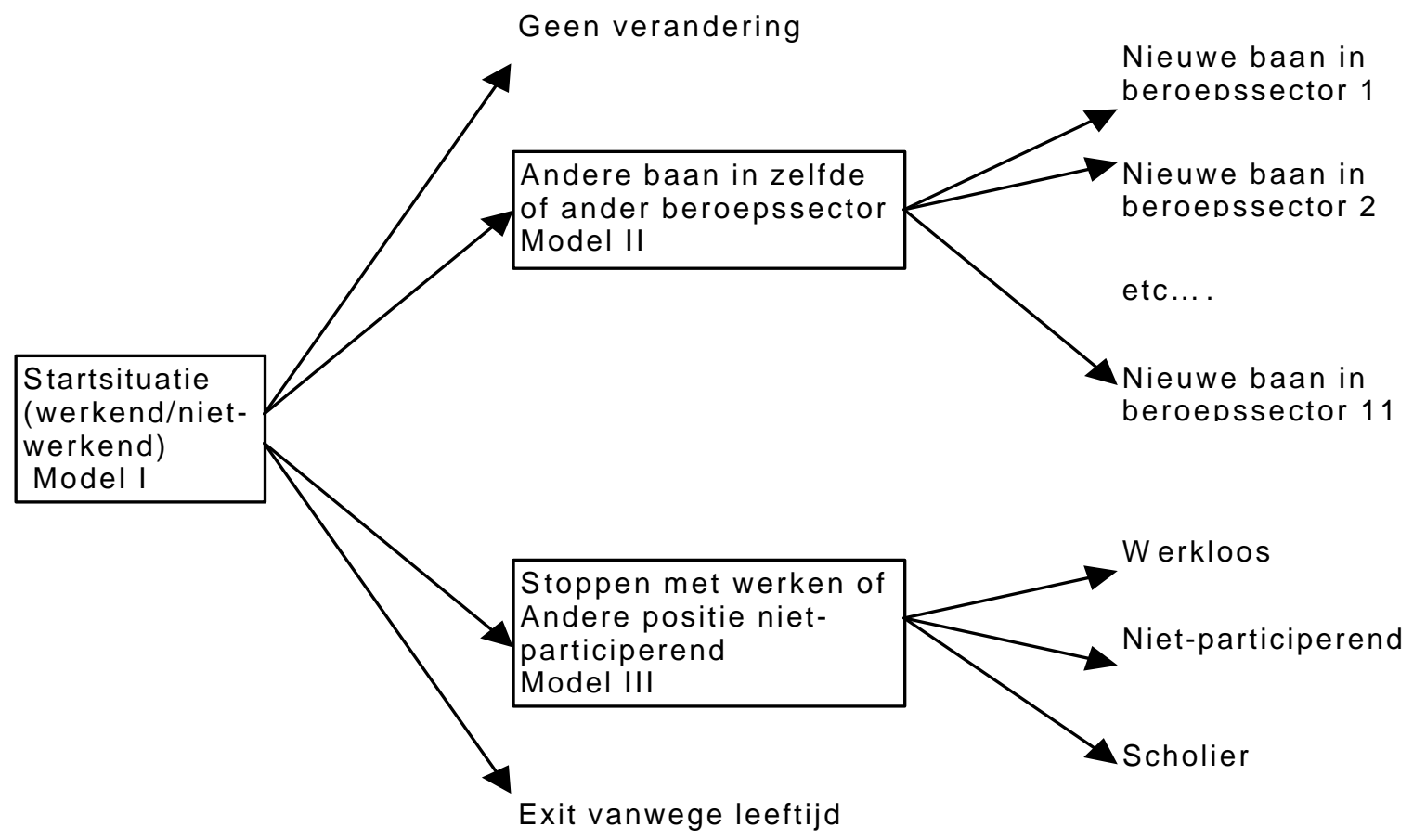


Het model waarvan hier wordt uitgegaan is in principe een beroepenmodel. Er wordt onderscheid gemaakt naar een aantal posities op de arbeidsmarkt: Daarbij wordt er een onderscheid gemaakt tussen werkend en niet-werkend. De werkenden zijn vervolgens onderverdeeld naar de 11 beroepssectoren die onderscheiden worden. De niet-werkenden worden onderverdeeld in werklozen, niet-participerenden en scholieren. Bij elkaar bestaan er dus 14 mogelijke arbeidsmarktposities. Omdat het te verwachten is dat de beslissing c.q. de kans om te stoppen met werken waarschijnlijk niet samenvalt met de beslissing om van baan te veranderen, is er voor gekozen een samengesteld model te hanteren. De opbouw van dit model is weergegeven in figuur 3 . Er is sprake van drie afzonderlijke modellen. Ten eerste een model dat beschrijft of men van positie op de arbeidsmarkt verandert: hierbij zijn er drie opties: of men verandert niet van positie, of men gaat werken in een (ander) beroep, of men stopt met werken. Vervolgens wordt er een model geschat dat verklaart - gegeven het feit dat men gaat werken in een (ander) beroep - naar welk beroep men gaat, en een ander model dat verklaart - gegeven het feit dat men stopt met werken - wat de positie zal zijn (werkloos, niet-participerend of scholier). Volgens deze opzet kan voor iedereen bepaald worden wat de kans is dat hij - gegeven zijn startpositie - het volgende jaar in een andere positie is.

In navolging van de in Borghans et al. (1998a) en De Grip en Vlasblom (1999b) gebruikte modellen is een multinomiaallogitmodel gekozen als econometrische specificatie van de diverse overgangskansen. In principe kunnen in een dergelijk model zowel kenmerken van het individu die voor alle bestemmingen gelijk zijn (bijvoorbeeld opleiding, leeftijd, geslacht) als kenmerken van de diverse bestemmingen als verklarende factoren opgenomen worden (Zie bijvoorbeeld Maddala, 1983, blz 41-46). Omdat echter de bestemmingen voor alle individuen gelijk zijn, is er geen variatie aanwezig in deze bestemmingsspecifieke verklarende gegevens. De kansen moeten derhalve volledig gerelateerd worden aan de persoonlijke kenmerken in de startpositie.

Voor alle modellen wordt uitgegaan van de volgende empirische specificatie, waarbij de likelihoodfunctie als volgt gespecificeerd is:

$$
\log L=\sum_{i=1}^{n} \sum_{j=1}^{m} y_{i j} \log P_{i j}
$$

met:

$$
P_{i j}=\frac{\exp \left(x_{i}^{\prime}, \beta_{k}\right)}{1+\sum_{k=1}^{m-1} \exp \left(x_{i}^{\prime}, \beta_{k}\right)}, j=1,2, \ldots, m-1
$$

en:

$$
P_{i m}=\frac{1}{1+\sum_{k=1}^{m-1} \exp \left(x_{i}^{\prime} \beta_{k}\right)}
$$


Hierbij staat het subscript $i$ voor de individuen, en $j$ voor de keuzemogelijkheden die voor dat individu openstaan. De variabele $y_{i j}$ is een dummyvariabele die aangeeft welke optie door het desbetreffende individu gekozen wordt. In deze specificatie van het model zijn de kenmerken $x_{i}$ alleen individu-specifiek, en niet afhankelijk van de keuzemogelijkheden. De geschatte parametervectoren $\beta_{j}$ zijn specifiek voor de keuzemogelijkheden, maar gelijk tussen de individuen.

Hoewel in de toekomst een andere aanpak denkbaar is, wordt in dit werkdocument uitsluitend gebruik gemaakt van de gegevens uit het SEP (als microbestand) en de EBB (als macrobestand). Omdat het micro-economische model voor de overgangskansen geschat wordt op basis van gegevens uit het SEP kunnen de overgangskansen geschat worden op basis van gedetailleerde informatie op individueel niveau: leeftijd, beroep, opleidingstype, inkomen etc. Omdat echter de uitkomsten van het micromodel gekoppeld moeten worden aan een geaggregeerd databestand, is dit niet mogelijk. Er moet daarom gebruik gemaakt worden van een beperkt aantal verklarende factoren die zowel in het micro- als in het macrobestand voorhanden zijn. In principe wordt het dan mogelijk om door middel van een aantal dummyvariabelen een 'type' respondent te definiëren. Voor ieder 'type' is dan een reeks overgangskansen te bepalen. De mate waarin een en andere uitgewerkt kan worden hangt in hoge mate samen met de kwaliteit van de data. Het aggregatieniveau waarop het model gebaseerd is, zou dusdanig moeten zijn dat het geschatte model op dat niveau gebruikt kan worden om betrouwbare prognoses mee te maken. Een eerste vereiste om de uitkomsten van het model betrouwbaar te houden, is dat de onderverdeling van de steekproef zo moet zijn dat de celvulling voldoende groot blijft. De beschikbare databestanden zijn relatief klein, zodat er een dilemma ontstaat tussen de bruikbaarheid van de resultaten vanuit het oogpunt van de gebruiker, en de betrouwbaarheid van de resultaten vanuit een statistisch oogpunt. Omdat de gebruiker in principe weinig heeft aan resultaten op een laag aggregatieniveau die onbetrouwbaar zijn, zal het statistisch bezwaar tegen een laag aggregatieniveau zwaarder wegen dan het gebruikersbezwaar tegen een hoog aggregatieniveau. Wel zal nagegaan moeten worden wat het laagst mogelijke niveau is dat acceptabel is vanuit statistisch oogpunt. Er is in eerste instantie gekozen voor een indeling naar een beperkt aantal kenmerken: arbeidsmarktpositie, geslacht, leeftijd, opleidingsniveau en opleidingsrichting.

Als de prognoses op hoog aggregatieniveau betrouwbaar zijn, kan wel altijd tot een verbijzondering per beroepssector worden overgegaan. Bij deze verbijzondering kunnen beschikbare microdata zoals die in het kader van andere onderzoeken ter beschikking komen een nuttige aanvulling zijn. Deze afzonderlijke deelprojecten zouden in dit kader ook een bredere setting kunnen krijgen, omdat in dat geval duidelijker is wat de positie van het deelsegment is ten opzichte van de diverse andere segmenten. Ook is uit sectorinformatie doorgaans wel duidelijk wat de samenstelling is van de mobiliteit binnen een sector, maar is van de in- en uitstroom uit de sector zelden meer bekend dan leeftijd en opleidingsniveau. Het 'grote' model zou hier meer inzicht in kunnen geven.

Informatie over de optredende stromen, en de kenmerken van de groep niet-participerenden als geheel kunnen verkregen worden op basis van de EBB en het SEP, beide van het CBS. 
Vooral de data van het SEP zijn van belang, omdat ze het mogelijk maken individuele overgangen te bestuderen: met name de vraag in hoeverre niet-participerenden weer gaan participeren, en onder welke omstandigheden dit gebeurt, is vanuit de informatiebehoefte interessant. Met betrekking tot de overgangen is er wel een aantal kleinere punten ten aanzien van de nauwkeurigheid waarmee de overgangen gemeten worden. De in het model gehanteerde classificatie is gebaseerd op de 'belangrijkste' bezigheid. Kleine verschuivingen in bezigheden tussen twee jaren kunnen een overgang suggereren. Dit doet zich bijvoorbeeld voor bij een niet-participerende die een deeltijdopleiding volgt, en de intensiteit van de opleiding uitbreidt tot een voltijds opleiding, of iemand die een kleine deeltijdbaan heeft ( $<12$ uur per week), en twee dagen gaat werken. In deze gevallen lijkt er een grote verandering plaats te vinden terwijl dit in wezen niet het geval is.

Naast de stromen die op basis van het model zelf voorspeld kunnen worden, zijn er ook stromen die exogeen bepaald worden. Een daarvan is de instroom van schoolverlaters op de arbeidsmarkt. Om een schatting te maken van de arbeidsmarktinstroom op korte termijn, gebruik gemaakt van prognoses van derden (De Referentieramingen van het Ministerie van Onderwijs, Cultuur en Wetenschappen). Deze aanpak is hetzelfde als de methode die ook voor de middellangetermijnprognoses wordt gehanteerd. Het voordeel van deze aanpak is dat er een zeer nauwe aansluiting bij de huidige prognosemethodiek voor de middellangetermijn behouden kan blijven. Het nadeel is dat deze aanpak nauwelijks een 'inhoudelijke component' kent, waarmee uitspraken gedaan kunnen worden over de aard en omvang van de stromen. Een andere mogelijkheid is dus om net zoals dat voor de werkenden gedaan wordt, een stromenmodel op te stellen dat de instroom op de arbeidsmarkt en de doorstroom in het (initiële) onderwijs verklaart. Het voordeel hiervan is dat dit beter aansluit bij de voor de overige stromen gebruikte methode. Dit vereenvoudigt - in het algemeen gesproken - de interpretatie van de uitkomsten, en zal daardoor bijvoorbeeld simulaties eenvoudiger maken.

Een verklarend model kan gebaseerd worden op het Schoolverlaters Informatie Systeem (SIS) van het ROA. Op basis van deze data is bekend welk deel van de schoolverlaters per opleidingstype kiest voor een vervolgopleiding, en op basis waarvan deze keuze gemaakt wordt. Hierbij kan gedacht worden aan arbeidsmarktkansen en het loopbaanperspectief. Door op basis van de feitelijke beslissing en achtergrondkenmerken aan elkaar te relateren kan een prognose gemaakt worden van de mate waarin scholieren een vervolgopleiding beginnen. Deze doorstroom in het onderwijs en de demografische bepaalde instroom in het onderwijs bepalen samen de totale jaarlijkse instroom in het onderwijs. De uitstroom uit het onderwijs kan eveneens geanalyseerd worden op basis van de SIS-data. Op basis van deze data is bekend welke opleiding mensen gevolgd hebben. Als zij niet kiezen voor een vervolgopleiding zal het vervolgens afhangen van de match tussen de kwalificaties waarover men beschikt en de op dat moment beschikbare vacatures of zij een baan vinden, of werkloos worden. Verdere uitwerking van deze component verdient aandacht in de verdere ontwikkeling van de prognosemethodiek. 


\subsection{Het gehanteerde aggregatieniveau}

Zoals hierboven is aangegeven maakt de structuur van het model het noodzakelijk om in het model dat de overgangskansen beschrijft, gebruik te maken van verklarende variabelen in de vorm van dummy's. Dit maakt het vervolgens mogelijk om de uitkomsten van dit overgangsmodel te koppelen aan de gegevens over de totale populatie. Zoals gezegd worden er een paar kenmerken gehanteerd als verklarende factoren: arbeidsmarktpositie, geslacht, leeftijd en opleidingstype. In deze paragraaf wordt er aangegeven hoe deze kenmerken opgenomen worden in de analyses.

In totaal worden er 14 mogelijke arbeidsmarktposities onderscheiden. Allereerst de indeling in werkend, werkloos, niet-participerend of voltijds scholier. De groep werkenden is vervolgens onderverdeeld naar de beroepssector waarin zij werkzaam zijn. Bij deze onderverdeling is aansluiting gezocht bij de door ROA gehanteerde beroepenindeling: er wordt gebruik gemaakt van de 11 beroepssectoren zoals die in De Arbeidsmarkt naar Opleiding en Beroep tot 2004 onderscheiden worden. In schema 1 staan deze 11 sectoren vermeld. Voor een overzicht van de beroepsgroepen die tot deze sectoren gerekend worden wordt verwezen naar de Statistische Bijlage bij De Arbeidsmarkt naar Opleiding en Beroep tot 2004 (ROA, 1999b). Wat ontbreekt in de indeling is het onderscheid naar beroepen op een laag en op een hoog niveau. Waarschijnlijk is een deel van de beroepenmobiliteit mobiliteit van laag naar hoog niveau. Zeker als het gaat om knelpuntenbepaling is dit onderscheid waarschijnlijk van belang, omdat instroom in de groep werkenden waarschijnlijk beperkt is tot laag niveau, terwijl de doorstroom voor de vulling van de hogere beroepen zorgt. De celvulling bleek echter te laag om dit onderscheid te kunnen maken.

\section{Schema 1}

Beroepssector

aantal beroepsgroepen per sector

$\begin{array}{lr}\text { Pedagogische beroepen } & 18 \\ \text { Culturele beroepen } & 4 \\ \text { Agrarische beroepen } & 7 \\ \text { Technische- en industrieberoepen } & 34 \\ \text { Transportberoepen } & 5 \\ \text { Medische- en paramedische beroepen } & 8 \\ \text { Economisch-administratieve beroepen } & 23 \\ \text { Informaticaberoepen } & 4 \\ \text { Sociaal-culturele beroepen } & 5 \\ \text { Verzorgende- en dienstverlenende beroepen } & 10 \\ \text { Openbare orde- en veiligheidsberoepen } & 4\end{array}$

Bron:ROA

De leeftijd wordt in drie categorieën samengevat. De jongeren in de leeftijdscategorie van 16 tot en met 34 jaar, de mensen van 'middelbare leeftijd' in de categorie 35-49 jaar en de ouderen in de leeftijdscategorie 50-64 jaar. De leeftijdsgrens die gekozen is voor de jongeren wijkt af van de in de Statistische Bijlage van De Arbeidsmarkt naar Opleiding en Beroep tot 
2004 (ROA, 1999b) gehanteerde. Daar wordt voor de jongeren de leeftijdscategorie 16-29 gehanteerd. Het bleek echter bij de schattingen dat het leggen van de grens bij 35 tot betere resultaten leidt.

Ook de opleiding wordt in een beperkt aantal categorieën gebruikt. Ook hierbij doet zich de vraag voor op welk aggregatieniveau de opleiding in het model opgenomen moet worden. Alleen per opleidingsniveau is waarschijnlijk te weinig, maar om op basis van de toch relatief beperkte databestanden die op dit moment beschikbaar zijn per ROA-opleidingstype te gaan werken levert een veel te lage celvulling op met alle bijbehorende econometrische problemen. Een tussenvorm kan gevonden worden in een indeling in een 4-tal niveaus en 5 hoofdrichtingen, zodat er ongeveer 20 categorieën geanalyseerd worden. We veronderstellen daarbij dat het effect op de overgangskansen van het opleidingsniveau onafhankelijk is van het effect van de opleidingsrichting. Hierbij moet ook opgemerkt worden dat niet alle 20 cellen gevuld zijn: het eerste niveau kent bijvoorbeeld maar één richting. In schema 2 staan de onderscheiden opleidingssectoren vermeld. Vanwege de noodzakelijke koppeling met het SEP is er geen één-op-één koppeling met de door het ROA gehanteerde indeling mogelijk, hoewel de indeling in grote lijnen overeenkomt met de sectorindeling die in De Arbeidsmarkt naar Opleiding en Beroep tot 2004 gehanteerd wordt. De in het schattingsmodel gehanteerde indeling is namelijk gebaseerd op de 3-digit SOI-code die beschikbaar is in SEP terwijl de ROA-indeling is gebaseerd op de 5-digit SOI-code die in SEP helaas niet beschikbaar is.

Schema 2

De 4 onderscheiden opleidingsniveaus en 5 richtingen

Opleidingsniveau SOI ( $\left(^{\mathrm{e}}\right.$ digit $)$

\begin{tabular}{lll} 
& & \\
1 & Basisonderwijs & $0-2$ \\
2 & VMBO & 3 \\
3 & MBO & 4 \\
4 & HBO/WO & $5-7$ \\
\hline
\end{tabular}

Opleidingsrichting $\quad$ SOI $\left(2^{\mathrm{e}}\right.$ en $3^{\mathrm{e}}$ digit $)$

1 Algemeen

2 Landbouw/Techniek

3 Econ.administr./Juridisch

4 (Para)medisch

5 Onderwijs/Soc.Cult.
00-01, 95-99

20-49, $\quad 90-94$

60-62, 65-66

50-54, 80-84

05-16, $\quad 70-71, \quad 85-86$

In totaal worden er dus $1680\left(14^{\star} 2^{*} 3^{*} 4^{*} 5=1680\right)$ afzonderlijke 'typen' onderscheiden. De totale populatie bedraagt ongeveer 10 miljoen mensen, zodat de gemiddelde (opgehoogde) celvulling zo'n 500 à 600 individuen bedraagt. Dit lijkt een redelijk compromis tussen detailleringsniveau en betrouwbaarheid. Deze indeling bepaalt dus ook de verklarende factoren 
die gehanteerd kunnen worden in de overgangsmodellen. Uiteraard kunnen in deelstudies bepaalde factoren wel verder uitgewerkt worden, maar de uitkomsten hiervan kunnen in principe niet gebruikt worden om de prognoses te maken. Overigens is het wel zo dat die delen van het model waarvoor geen zinvol model geschat kan worden, met behulp van vaste coëfficiënten verbijzonderd kunnen worden. Te denken valt hierbij aan de verdeling van de diverse stromen over de lagere aggregatieniveaus of aan het opleggen van vaste uitstroomcoëfficiënten voor die groepen waarvoor te weinig waarnemingen zijn om een 'zinvol' model te specificeren.

\subsection{Empirische resultaten}

Hierboven is aangegeven hoe de structuur van het model is. In deze paragraaf staat een nadere uitwerking. Het model is geschat op basis van een drietal jaargangen van het Sociaal Economisch Panel (1994-1996). Op basis hiervan is een bestand geconstrueerd waarin bijna 14.000 waarnemingen zijn geconstrueerd, die betrekking hebben op een overgang van het ene naar het andere jaar. De mobiliteit wordt gemeten door de opgegeven arbeidsmarktpositie en beroepen te vergelijken. De op deze manier gemeten mobiliteit kan een overschatting inhouden van de werkelijke mobiliteit. Dit kan gebeuren doordat er coderingsfouten en onnauwkeurigheden bij de beroepscodering op kunnen treden. Er bestaat in principe geen manier om te controleren voor foute coderingen, zodat we er van uit moeten gaan dat iedere verandering in SBC ook een daadwerkelijke verandering op de arbeidsmarkt inhoudt. Dit lijkt vooral een probleem bij het onderscheid tussen werkloos en niet-participerend. Het is duidelijk uit de tabel dat er een zeer grote mobiliteit tussen deze beide situaties is: $33 \%$ van de werklozen in het eerste jaar geeft het jaar daarop aan niet-participerend te zijn, terwijl $11 \%$ van de niet-participerenden aangeeft het jaar daarop werkzoekend te zijn. Omdat deze beide stromen nominaal ongeveer even groot zijn, blijft de verhouding tussen werklozen en niet-participerenden ongeveer gelijk. Om de 'schijnmobiliteit' zoveel mogelijk te beperken, is gecorrigeerd door het aanvangsjaar van de huidige betrekking te gebruiken ${ }^{2}$.

De waargenomen mobiliteit staat weergegeven in tabel 1. In deze tabel staat de arbeidsmarktpositie op twee opvolgende enquêtemomenten weergegeven. Er is een vrij grote mobiliteit te onderscheiden. Afhankelijk van de startsituatie waarin men zich bevindt, blijft ongeveer $80 \%$ in dezelfde situatie, ca. $13 \%$ maakt de overgang naar een nieuwe baan in dezelfde of een andere beroepssector, en ca. $7 \%$ stopt met werken. Ter vergelijking: in Borghans e.a. (1998a) werd op basis van de pensioengegevens voor de zorgsector een netto-uitstroom van ca. $12 \%$ per jaar gemeten, terwijl hier voor de (para)medische beroepen een netto-uitstroom van $13 \%$ gevonden is, waarvan $11 \%$ baan-baanmobiliteit betreft.

De omvang van de mobiliteit is sterk afhankelijk van de startsituatie: de werkenden in de eerste beroepssector (de pedagogische beroepen) kennen een relatief lage mobiliteit, die in

2 Het blijkt dat deze correctie de mobiliteit met 12 procentpunten doet afnemen. Met name de mobiliteit van en naar beroepssectoren 4 en 7 neemt sterk af. Dit lijkt er op te duiden dat de codering van de beroepen in deze beide sectoren met relatief grote codeerfouten gepaard gaat. 
het tweede sector (de culturele beroepen) kennen juist een relatief hoge mobiliteit. Er is ook een verschil tussen de sectoren met betrekking tot de mate waarin 'mobiele' werkenden hun oude beroep inruilen voor een nieuw beroep: Deze verschillen zijn echter niet zo heel groot. In bijvoorbeeld de verzorgende beroepen blijft het $80 \%$ van de 'mobielen' binnen hetzelfde sector, terwijl binnen de culturele beroepen ca. $73 \%$ binnen dezelfde sector blijft. In de afgelopen twee jaren blijken met name de economisch-administratieve beroepen een grote aantrekkingskracht gehad te hebben voor werkenden vanuit alle sectoren. Het is uit deze tabel wel duidelijk dat er met name daar waar het de studerenden betreft een verdere uitwerking nodig is: bepaalde beroepssectoren kennen geen instroom vanuit de studerenden, iets wat tot een vertekening kan gaan leiden in de prognoses.

In totaal zijn er ongeveer 2.500 'echte veranderingen' waarop het model geschat kan worden. Dit lijkt in eerste instantie een voldoende groot aantal. Als er in de toekomst recentere jaargangen van het SEP beschikbaar komen kan het aantal waarnemingen verder uitgebreid worden. Het gebruiken van meerdere jaargangen van het SEP moet hierbij afgewogen worden tegen de longitudinale stabiliteit van de parameters: gedrag van mensen verandert door de tijd, waardoor het gebruik van oudere jaargangen resulteert in een betere celvulling, en dus statistisch gezien betere resultaten, maar mogelijk een minder goede inschatting van het huidige gedrag van mensen. Deze afweging zal pas gemaakt kunnen worden door na een aantal jaren een goede evaluatie van het model te maken.

Op basis van de mobiliteit die waargenomen wordt in het SEP wordt er een drietal modellen geschat. Het eerste model verklaart of er een verandering optreedt in de arbeidsmarktpositie. Het tweede model verklaart naar welk beroep men gaat als er sprake is van beroepenmobiliteit. Het derde model verklaart naar welke vorm van 'niet-werken' men gaat als men stopt met werken. De mobiliteit die in tabel 1 vermeld staat zal worden gerelateerd aan de huidige positie op de arbeidsmarkt, geslacht, leeftijd en de gevolgde opleiding. De genoemde verklarende factoren zijn persoonskenmerken, en dus identiek voor alle keuzemogelijkheden. Naast de persoonskenmerken zijn ook arbeidsmarktomstandigheden mogelijk van belang. Hierbij kan gedacht worden aan bijvoorbeeld 'belastende factoren' waarmee iemand in zijn werk te maken krijgt (bijvoorbeeld Diephuis e.a., 2000). Daarnaast zal de arbeidsmarktsituatie van belang zijn bij de beslissing om mobiel te worden. Hierbij kan dan gedacht worden aan bijvoorbeeld de mogelijkheden (of verplichting) die iemand heeft om mobiel te worden zoals die tot uiting komt in de groei en krimp van het eigen beroep of juist in de andere beroepen (zie Willems e.a., 1997, Borghans e.a., 1998a). Maar daarnaast kan er ook gedacht worden aan bijvoorbeeld de ontwikkeling van het eigen inkomen gerelateerd aan de inkomensontwikkeling in andere beroepssectoren. Voor al deze factoren geldt echter dat ze in hoge mate beroepsspecifiek zijn. Omdat het model geschat wordt voor de verschillende beroepssectoren afzonderlijk, betekent dit dat er geen variatie in die kenmerken optreedt tussen individuen. Met andere woorden, de effecten van deze factoren zijn niet identificeerbaar, en worden weergegeven door de constante term. Ditzelfde geldt voor de kenmerken van de beroepen waarnaar men toe kan: ook hier zijn de kenmerken afhankelijk van het desbetreffende beroep, en niet van het individu. Hierdoor is ook het effect van deze kenmerken niet identificeerbaar binnen het huidige model. 
Van alle verklarende factoren verdient de opleiding nog een kleine toelichting. Het model verklaart nu nog geen veranderingen in het opleidingsniveau. Als dit in een later stadium wel gebeurt, moet ook de consistentie van de codering van het opleidingsniveau door de tijd gecontroleerd worden. Ook hier is het namelijk mogelijk dat we veranderingen van opleidingstype 'zien' die uitsluitend het gevolg zijn van codeerfouten op één van beide enquêtemomenten.

In tabel 2 staat een indicatie van de opleidingsverdeling zoals die binnen de diverse beroepssectoren waargenomen wordt. Bij deze tabel moet wel bedacht worden dat vanwege dataproblemen er voor dit werkdocument gebruik gemaakt is van een geconstrueerd populatiebestand op basis van het SEP, dat bij benadering opgehoogd is naar EBB-aantallen. Op dezelfde manier als in deze tabel kunnen er ook verdelingen van opleidingsrichtingen, leeftijd en geslacht per arbeidsmarktpositie gegeven worden. Op die manier levert ook de input voor het model nuttige beschrijvende informatie op: de waargenomen mobiliteit is zeer waardevol voor de loopbaanoriëntatie, omdat dit aangeeft in hoeverre er blijkbaar mogelijkheden bestaan om gegeven een opleidingtype, een bepaalde overgang te maken. Gedacht kan voor deze informatie worden aan een tabel die per opleidingsachtergrond voor iedere beroepssector de meest voorkomende bestemmingen weergeeft. Of er kan in een tabel per beroep en opleidingstype de meest gebruikelijke herkomstplekken worden weergegeven. Met andere woorden: waar bevindt zich mijn wervingspotentieel? In dat geval is de informatie meer geschikt vanuit werkgeversoogpunt.

Er worden in totaal drie modellen geschat voor iedere startsituatie, dus in totaal 42 multinomialelogitmodellen. Uit tabel 1 is af te leiden dat het aantal waarnemingen waarop deze modellen geschat worden in sommige gevallen erg klein is. Model I (het model dat mobiliteit verklaart) wordt voor beroepssector 2 en 11 op een net iets meer dan honderd waarnemingen geschat. Het moge duidelijk zijn dat verdere opsplitsing van deze beroepssectoren tot numerieke problemen gaat leiden. Model II wordt uitsluitend geschat met gebruikmaking van de waargenomen beroepsmobiliteit. Ook dit levert voor sommige beroepssectoren kleine aantallen waarnemingen op. Zeker als bedacht wordt dat dit model in principe 11 verschillende bestemmingscategorieën kent. Voor beroepssector 1 wordt er gebruik gemaakt van 36 waarnemingen verdeeld over 3 verschillende bestemmingen. Ditzelfde probleem doet zich ook voor bij het model dat de aard van de niet-participatie verklaart. De schattingen die tot nu toe gemaakt zijn, leren dan ook dat het goed mogelijk is om een verklarend model te schatten dat het optreden van mobiliteit verklaart, maar dat voor de andere twee modellen, een vastecoëfficiëntenverdeling gebruikt moet worden zolang het aantal waarnemingen niet groter is.

In tabel 3 staan de schattingsresultaten vermeld voor het eerste model voor de pedagogische beroepen (beroepssector 1 ). 
Tabel 1

Mobiliteit van werkenden, procentuele verdeling en totalen, 1994-1996

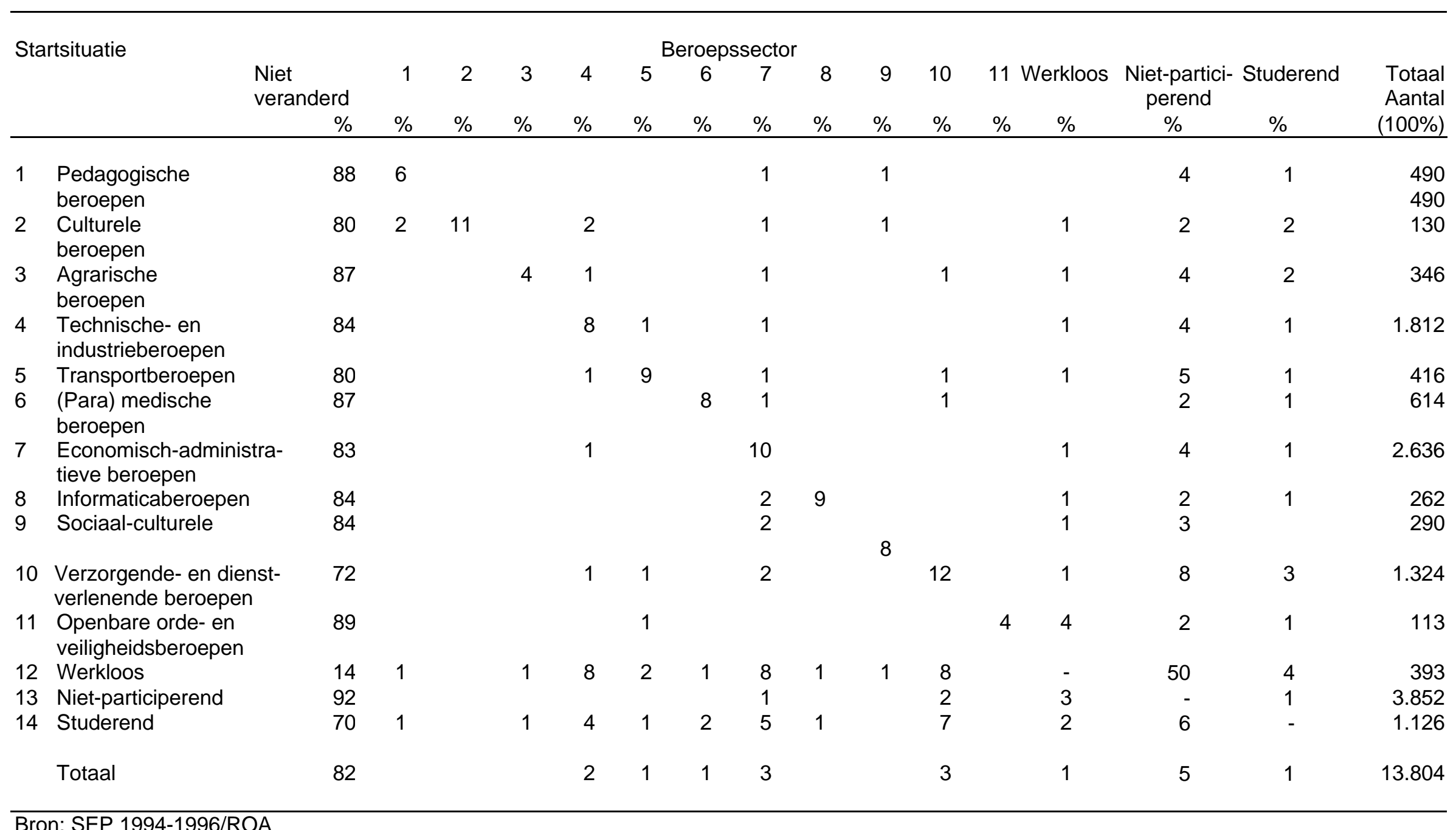


Tabel 2

Omvang populatie en verdeling over opleidingsniveaus, gefingeerde cijfers

\begin{tabular}{|c|c|c|c|c|c|c|}
\hline \multicolumn{2}{|c|}{ Beroepssector } & \multirow{2}{*}{$\begin{array}{c}\begin{array}{c}\text { Basisonderwijs } \\
\%\end{array} \\
1\end{array}$} & \multirow{2}{*}{$\begin{array}{c}\text { VMBO } \\
\% \\
1\end{array}$} & \multirow{2}{*}{$\begin{array}{c}\text { MBO } \\
\%\end{array}$} & \multirow{2}{*}{$\begin{array}{c}\mathrm{HBO} / \mathrm{WO} \\
\% \\
85\end{array}$} & \multirow{2}{*}{$\begin{array}{r}\begin{array}{r}\text { Totaal } \\
(\times 1.000)\end{array} \\
234\end{array}$} \\
\hline 1 & Pedagogische beroepen & & & & & \\
\hline 2 & Culturele beroepen & 3 & 2 & 37 & 58 & 131 \\
\hline 3 & Agrarische beroepen & 10 & 25 & 50 & 15 & 275 \\
\hline 4 & Technische- en industrieberoepen & 11 & 26 & 50 & 13 & 1.446 \\
\hline 5 & Transportberoepen & 19 & 40 & 33 & 7 & 370 \\
\hline 6 & (Para) medische beroepen & 2 & 7 & 51 & 40 & 375 \\
\hline 7 & Economisch-administratieve beroepen & 4 & 17 & 50 & 29 & 1.871 \\
\hline 8 & Informaticaberoepen & 1 & 7 & 41 & 51 & 184 \\
\hline 9 & Sociaal-culturele beroepen & 3 & 4 & 36 & 56 & 205 \\
\hline \multirow[t]{2}{*}{10} & Verzorgende- en dienstverlenende & & & & & \\
\hline & beroepen & 10 & 31 & 49 & 10 & 1.042 \\
\hline 11 & Openbare orde- en veiligheidsberoepen & 4 & 20 & 65 & 11 & 108 \\
\hline
\end{tabular}

Bron: ROA/SEP 1994-1996 
Tabel 3

Schattingen voor het mobiliteitsmodel, pedagogische beroepen

\begin{tabular}{|c|c|c|c|c|}
\hline \multirow[t]{2}{*}{ Verklarende variabele } & \multicolumn{2}{|c|}{ Ander beroep } & \multicolumn{2}{|c|}{ Stoppen } \\
\hline & Coëf. & t-waarde & Coëf. & t-waarde \\
\hline Constante & $-4,204^{\star *}$ & $-3,25$ & $-14,207$ & $-0,17$ \\
\hline Geslacht (vrouw=1) & $1,210^{*}$ & 2,19 & $2,593^{*}$ & 2,40 \\
\hline \multicolumn{5}{|l|}{ Leeftijd } \\
\hline leeftijd $<34$ & $1,906^{\star *}$ & 2,95 & 1,786 & 1,24 \\
\hline leeftijd > 50 & 0,858 & 1,13 & $2,549^{\star}$ & 2,15 \\
\hline vrouw*leeftijd < 34 & $-1,438$ & $-1,77$ & $-2,051$ & $-1,27$ \\
\hline vrouw*leeftijd > 50 & $-2,425$ & $-1,86$ & $-1,541$ & $-1,18$ \\
\hline \multicolumn{5}{|l|}{ Opleidingsniveau } \\
\hline Basisonderwijs & 1,665 & 1,00 & 1,048 & 0,01 \\
\hline VMBO (referentiecat.) & & & - & \\
\hline MBO & 0,976 & 0,74 & $-8,400$ & $-0,07$ \\
\hline HBO/WO & $-0,703$ & $-1,25$ & $-0,414$ & $-0,64$ \\
\hline \multicolumn{5}{|l|}{ Opleidingsrichting } \\
\hline Algemeen (referentiecat.) & - & & - & \\
\hline Landbouw & 0,989 & 0,70 & 9,889 & 0,12 \\
\hline Econ.-administratief & 1,396 & 0,98 & 9,746 & 0,11 \\
\hline (Para)medisch & 1,011 & 0,63 & 11,278 & 0,13 \\
\hline Onderwijs & 1,421 & 1,12 & 9,204 & 0,11 \\
\hline Aantal waarnemingen & 490 & & & \\
\hline Log. likelihood & $-179,8$ & & & \\
\hline
\end{tabular}

Bron: ROA

Bij model 3 wordt de situatie dat men niet van arbeidsmarktpositie veranderd als referentiecategorie gebruikt. De twee andere situaties zijn: verandering van baan, en stoppen met werken. Uit de schattingsresultaten valt op dat vrouwen een hogere kans op mobiliteit hebben dan mannen, waarbij vrouwen ook vaker stoppen dan van baan veranderen. Leeftijd heeft weinig effect, maar duidelijk is wel de uitstroom van werkend maar niet-participerend onder ouderen hoger is dan onder jongeren. Hoewel maar nauwelijks significant, lijkt het zo te zijn dat als vrouwen na hun $50^{\mathrm{e}}$ nog werken, dat ze dan juist langer doorwerken dan mannen van dezelfde leeftijd: de uitstroom van vrouwen ouder dan 50 is lager dan die van de mannen. Het opleidingsniveau doet voor de verklaring van de mobiliteit niet ter zake, er is een lichte tendens voor hoger opgeleiden een lagere uitstroom te hebben. Zoals eerder al opgemerkt werd is het in de huidige opzet van het model niet mogelijk om kenmerken per beroepssector op te nemen, omdat die geen variatie vertonen tussen individuen of tussen keuzeopties. Het effect van deze beroeps- en arbeidsmarktkenmerken is dus niet identificeerbaar binnen de huidige modelopzet.

De schattingsresultaten voor de overige 13 startsituaties leveren vergelijkbare resultaten op, alhoewel er uiteraard verschillen zijn in omvang van de effecten en hun significantie. Het 
schatten van de andere twee modellen leverde meer problemen op. Het blijkt dat er nauwelijks voldoende waarnemingen zijn met daarbinnen voldoende variatie om een inhoudelijk model te kunnen schatten. $\mathrm{Er}$ is daarom voor gekozen om beide modellen te beperken tot een model met uitsluitend een constante term. Dit houdt in feite in dat er gebruik gemaakt wordt van een vaste verdeling, gebaseerd op de waargenomen mobiliteit in tabel 1.

\section{Prognoses}

\subsection{Inleiding}

De schattingsresultaten uit het vorige hoofdstuk kunnen gebruikt worden om een aantal prognoses te maken. Allereerst zijn dat prognoses met betrekking tot de ontwikkeling van het aantal werkenden naar beroep en opleiding. Dit levert zoals in paragraaf 5.2 getoond wordt verwachte discrepanties per opleiding of beroep. Daarnaast kan met het model ook een prognoses gemaakt worden van de verwachte verdeling van de in- en uitstroom per beroep of opleiding. In paragraaf 5.3 wordt hier een aantal voorbeelden van getoond. Paragraaf 5.4 gaat in op de verwachte baanmobiliteit. Tot slot wordt in paragraaf 5.5 ingegaan op de vraag hoe met de informatie uit dit hoofdstuk voorzien kan worden in de informatiebehoefte zoals die in hoofdstuk 2 is geschetst. De cijfers zoals die in dit hoofdstuk gepresenteerd worden, zijn gebaseerd op een geconstrueerd populatiebestand en kunnen dus niet als prognoses beschouwd worden, ze dienen uitsluitend het doel de methodiek te illustreren.

\subsection{Verwachte overschotten en tekorten}

Zoals uit de voorgaande algemene beschrijving gebleken is, is het model in staat om uitspraken te doen over de mobiliteit van werkzoekenden en werkenden op de arbeidsmarkt. Uiteraard gaat het dan in eerste instantie om een beschrijving van de patronen uit het verleden, maar als er van uitgegaan wordt dat de mobiliteitskansen in de nabije toekomst in dezelfde mate van deze kenmerken af blijven hangen, kunnen met het model prognoses gemaakt worden voor de verwachte stromen. Door de verwachte mobiliteit op te splitsen naar startsituatie, bestemming, kenmerken etc, kan aan een groot deel van de in de vorige hoofdstukken geschetste informatiebehoefte voldaan worden.

Uitgaande van het model kan de volgende informatie gegenereerd worden: de omvang van de diverse brutostromen, en de daaruit resulterende nettostromen. In tabel 4 worden deze samengevat door uitsluitend de verwachte ontwikkeling voor de verschillende beroepssectoren te tonen. In deze tabel staat allereerst de omvang van de startpopulatie aan het begin van de prognoseperiode. De aantallen die hier genoemd zijn hebben geen betrekking op een jaar maar zijn gefingeerde cijfers. Daarnaast staat de totale (bruto)-uitstroom en de totale (bruto)-instroom voor deze 11 beroepssectoren. Deze totale bruto uit- en instroom leveren een verwachte netto-instroom per beroep. Door deze prognose te relateren aan de uitbreidingsvraag, ontstaat een indicatie van de discrepanties (hierbij is een min een overschot). Zoals te zien is wordt er op termijn van een jaar een groot overschot aan werkenden 
voorspeld. Door de opbouw van de in- en uitstroom nader te beschouwen kan nagegaan worden wat hier de oorzaak van is. Deze informatie over de stromen wordt in de volgende paragraaf gepresenteerd. Overigens moet ook hier weer met nadruk gesteld worden dat deze tabellen geen betrouwbare prognoses geven, omdat ze gebaseerd zijn op een geconstrueerde populatie. De uiteindelijke resultaten zullen naar alle waarschijnlijkheid afwijken van de hier getoonde.

Tabel 4

Populatieontwikkeling en discrepanties per beroepssector (x1.000)

\begin{tabular}{|c|c|c|c|c|c|c|}
\hline $\begin{array}{l}\text { Beroeps- } \\
\text { sector }\end{array}$ & Start & Uitstroom & Instroom & $\begin{array}{l}\text { Netto- } \\
\text { instroom }\end{array}$ & $\begin{array}{l}\text { Uitbreidings- } \\
\text { vraag }\end{array}$ & Discrepantie ${ }^{a)}$ \\
\hline 1 & 234 & 28 & 49 & 21 & 3 & -18 \\
\hline 2 & 131 & 28 & 22 & -6 & 1 & 8 \\
\hline 3 & 275 & 39 & 46 & 7 & -4 & -11 \\
\hline 4 & 1.446 & 239 & 263 & 25 & -42 & -67 \\
\hline 5 & 370 & 73 & 81 & 8 & 2 & -6 \\
\hline 6 & 375 & 49 & 78 & 29 & 2 & -27 \\
\hline 7 & 1.871 & 320 & 367 & 47 & 68 & 21 \\
\hline 8 & 184 & 29 & 42 & 12 & 10 & -3 \\
\hline 9 & 205 & 34 & 39 & 5 & 5 & 0 \\
\hline 10 & 1.042 & 296 & 347 & 51 & 21 & -30 \\
\hline 11 & 108 & 11 & 12 & 1 & 0 & -1 \\
\hline Totaal & 6.243 & 1.146 & 1.347 & 201 & 66 & -134 \\
\hline
\end{tabular}

a) Een negatief getal duidt op een overschot Bron: ROA

Door vraag en aanbod met elkaar te confronteren kunnen er in principe korte-termijn ITA's en ITKP's bepaald worden. Omdat van alle individuen zowel opleiding als beroep bekend zijn, en de uitbreidingsvraag ook per opleiding en beroep, kunnen de ITA's in principe per opleiding en beroep bepaald worden. Bij de bepaling per beroep moet dan wel bedacht worden dat de verdeling uit het verleden niet het feitelijke initiële aanbod weergeeft, maar de tot stand gekomen verdeling in de markt. Met andere woorden, er is in deze verdeling (en dus de geschatte overgangskansen) al een zeker aanpassingsproces opgenomen.

De informatie uit de voorgaande tabel kan ook per opleidingstype gepresenteerd worden. In tabel 5 staat per opleidingstype aangegeven wat de verwachte ontwikkelingen zullen zijn. Hierbij is niet de gehele populatie als uitgangspunt genomen, maar uitsluitend de werkende beroepsbevolking en de werklozen. In deze tabel is te zien in hoeverre de verwachte in- en uitstroom er toe leiden dat de uitbreidingsvraag via 'natuurlijk verloop' kan worden gerealiseerd. Zo is te zien dat bijvoorbeeld veel meer ongeschoolden hun baan verlaten dan dat er nieuw instromen. Er resteert hier, ondanks de negatieve uitbreidingsvraag, een zeer klein overschot aan ongeschoolden. Aan de andere kant lijkt er bij het hoger opgeleid personeel een overschot te ontstaan; de uitstroom is veel kleiner dan de instroom. Het in tabel 4 
gesignaleerde overschot wordt dus voornamelijk op het niveau van HBO/WO gerealiseerd. Hierbij geldt dan weer dezelfde kanttekening als bij de beroepen: de instroom van uit de nietparticiperenden is volledig meegeteld. Ook zegt deze tabel nog niets over de mismatch tussen de gevraagde en aangeboden kwalificaties: het is mogelijk dat hoewel er op een geaggregeerd niveau overschotten lijken te zijn, dit in de praktijk niet zo is, omdat het aanbod over de verkeerde kwalificaties beschikt.

\subsection{De verwachte brutostromen}

De in de vorige paragraaf getoonde verwachte ontwikkeling in het aantal werkenden is het gevolg van de optredende stromen. Het model laat toe om de onderliggende stromen nader te beschouwen. Ook hier geldt weer dat de stromen getoond kunnen worden per beroepssector of per opleidingstype. In tabel 6 en 7 worden de stromen getoond per beroepssector. Uit deze tabellen wordt direct duidelijk wat de oorzaak is van het verwachte overschot het komende jaar. Dit overschot is voornamelijk een gevolg van het aanbod van de niet-participerenden die weer willen gaan werken: Van de instroom bestaat $10 \%$ uit werklozen $(50 \%$ van de werklozen) en $14 \%$ uit niet-participerenden (4\% van de niet-participerenden) die weer terug (willen) keren naar de actieve beroepsbevolking. Deze twee groepen zijn samen goed voor zo'n 316.000 werkenden. In de MLT-benadering wordt dit aanbod niet expliciet meegeteld, maar uitsluitend voor zover deze mensen ook feitelijk een baan gevonden hebben. Dit maakt het lastig deze prognoses zonder meer te vergelijken met de bestaande.

Dezelfde informatie kan ook per opleidingstype gepresenteerd worden. In tabellen 8 en 9 staan de in- en uitstroom per opleidingssector weergegeven. Ook in deze twee tabellen valt op dat er een relatief grote mobiliteit plaatsvindt, zowel baanmobiliteit, als mobiliteit van en naar een 'inactieve' status op de arbeidsmarkt. Het blijkt dat de meeste mobiliteit optreedt naar een andere baan toe: $58 \%$ van de 'bruto-uitstromers' vertrekt naar een andere baan (al dan niet in dezelfde sector). De rest wordt ofwel werkloos (3\%), verdwijnt uit de actieve beroepsbevolking (32\%) of gaat terug naar school (6\%). Omdat er relatief weinig 64-jarigen in SEP zijn opgenomen wordt de uitstroom naar pensioen waarschijnlijk onderschat. Het is in de tabel te zien dat onder de laagopgeleiden het percentage dat werkloos wordt of terug gaat naar (voltijds) scholing, groter is dan onder de hogeropgeleiden. Deze hogeropgeleiden kennen eigenlijk voornamelijk baan-baanmobiliteit. Uitstroom naar het onderwijs vindt op alle niveaus plaats, maar is vooral op VMBO en MBO-niveau van belang. Het opleidingsniveau is niet van belang voor het percentage van de uitstroom dat werkloos wordt.

In tabel 9 worden de instroomcijfers opgesplitst. In deze tabel valt op dat slechts een deel van de vacatures vervuld wordt door een nieuwkomer op de arbeidsmarkt. Slechts $19 \%$ van de instromers is schoolverlater, $52 \%$ van de instromers komt uit een andere baan, terwijl $19 \%$ komt vanuit de niet-participerenden en de resterende $9 \%$ uit de groep werklozen. 
Tabel 5

Populatieontwikkeling en discrepanties per opleidingssector (x 1.000)

\begin{tabular}{|c|c|c|c|c|c|c|c|}
\hline $\begin{array}{l}\text { Opleiding- } \\
\text { niveau }\end{array}$ & Richting & Start & Uitstroom & Instroom & Netto-instroom & $\begin{array}{l}\text { Uitbreidings- } \\
\quad \text { vraag }\end{array}$ & Discrepantie $^{a}$ \\
\hline Basisonderwijs & Algemeen & 550 & 168 & 142 & -26 & -24 & 2 \\
\hline \multirow[t]{5}{*}{ VMBO } & Algemeen & 443 & 144 & 113 & -31 & 4 & 36 \\
\hline & Landbouw/Techniek & 513 & 100 & 89 & -11 & -21 & -9 \\
\hline & Economisch/Juridisch & 155 & 42 & 39 & -3 & 1 & 4 \\
\hline & (Para)medisch & 270 & 77 & 77 & 0 & -4 & -4 \\
\hline & Onderwijs/Soc.Cultureel & 30 & 10 & 9 & -1 & 0 & 1 \\
\hline \multirow[t]{5}{*}{ MBO } & Algemeen & 344 & 106 & 119 & 13 & 14 & 1 \\
\hline & Landbouw/Techniek & 1.052 & 166 & 162 & -4 & 9 & 13 \\
\hline & Economisch/Juridisch & 951 & 199 & 203 & 5 & 20 & 15 \\
\hline & (Para)medisch & 600 & 150 & 156 & 7 & 11 & 4 \\
\hline & Onderwijs/Soc.Cultureel & 138 & 32 & 33 & 1 & 4 & 3 \\
\hline \multirow[t]{5}{*}{$\mathrm{HBO} / \mathrm{WO}$} & Algemeen & 228 & 68 & 62 & -6 & 2 & 7 \\
\hline & Landbouw/Techniek & 303 & 46 & 62 & 16 & 7 & -9 \\
\hline & Economisch/Juridisch & 378 & 69 & 105 & 36 & 24 & -13 \\
\hline & (Para)medisch & 172 & 28 & 45 & 17 & 6 & -11 \\
\hline & Onderwijs/Soc.Cultureel & 538 & 102 & 116 & 13 & 15 & 1 \\
\hline Totaal & & 6.665 & 1.508 & 1.533 & 25 & 68 & 42 \\
\hline
\end{tabular}

a) Een negatief getal duidt op een overschot

Bron: ROA 
Tabel 6

Totale uitstroom per beroepssector naar bestemming

\begin{tabular}{|c|c|c|c|c|c|c|c|}
\hline $\begin{array}{l}\text { Beroeps- } \\
\text { sector }\end{array}$ & $\begin{array}{l}\text { Uitstroom } \\
(\times 1.000)\end{array}$ & $\begin{array}{c}\text { Zelfde } \\
\text { beroep } \\
\%\end{array}$ & $\begin{array}{c}\text { Ander } \\
\text { beroep } \\
\%\end{array}$ & $\begin{array}{c}\text { Werkloos } \\
\%\end{array}$ & $\begin{array}{l}\text { Niet-partici- } \\
\text { perend } \\
\%\end{array}$ & $\begin{array}{c}\text { Scholier } \\
\%\end{array}$ & $\begin{array}{c}\text { Pensioen } \\
\%\end{array}$ \\
\hline 1 & 28 & 45 & 15 & 0 & 33 & 7 & 0 \\
\hline 2 & 28 & 55 & 24 & 4 & 7 & 11 & 0 \\
\hline 3 & 39 & 26 & 20 & 4 & 29 & 15 & 5 \\
\hline 4 & 239 & 52 & 14 & 6 & 23 & 4 & 0 \\
\hline 5 & 73 & 45 & 18 & 5 & 25 & 8 & 0 \\
\hline 6 & 49 & 64 & 15 & 0 & 14 & 6 & 0 \\
\hline 7 & 320 & 56 & 13 & 4 & 24 & 3 & 0 \\
\hline 8 & 29 & 58 & 17 & 5 & 14 & 7 & 0 \\
\hline 9 & 34 & 46 & 26 & 7 & 20 & 2 & 0 \\
\hline 10 & 296 & 39 & 19 & 3 & 28 & 11 & 0 \\
\hline 11 & 11 & 33 & 8 & 33 & 17 & 8 & 0 \\
\hline Totaal & 1.146 & 49 & 16 & 4 & 24 & 7 & 0 \\
\hline
\end{tabular}

Tabel 7

Totale instroom per beroepssector naar herkomst

\begin{tabular}{|c|c|c|c|c|c|c|}
\hline $\begin{array}{l}\text { Beroeps- } \\
\text { sector }\end{array}$ & $\begin{array}{c}\text { Instroom } \\
(x 1.000)\end{array}$ & $\begin{array}{c}\text { Zelfde } \\
\text { beroep } \\
\%\end{array}$ & $\begin{array}{c}\text { Ander } \\
\text { beroep } \\
\%\end{array}$ & $\begin{array}{c}\text { Werkloos } \\
\%\end{array}$ & $\begin{array}{l}\text { Niet-partici- } \\
\text { perend } \\
\%\end{array}$ & $\begin{array}{c}\text { Scholier } \\
\%\end{array}$ \\
\hline 1 & 49 & 26 & 45 & 7 & 22 & 19 \\
\hline 2 & 22 & 70 & 15 & 5 & 10 & 5 \\
\hline 3 & 46 & 22 & 52 & 12 & 14 & 32 \\
\hline 4 & 263 & 47 & 33 & 13 & 7 & 20 \\
\hline 5 & 81 & 40 & 43 & 11 & 5 & 21 \\
\hline 6 & 78 & 40 & 36 & 4 & 20 & 28 \\
\hline 7 & 367 & 49 & 32 & 10 & 10 & 16 \\
\hline 8 & 42 & 41 & 44 & 10 & 5 & 25 \\
\hline 9 & 39 & 40 & 38 & 11 & 11 & 6 \\
\hline 10 & 347 & 33 & 33 & 10 & 24 & 27 \\
\hline 11 & 12 & 30 & 70 & 0 & 0 & 28 \\
\hline Totaal & 1.347 & 41 & 35 & 10 & 14 & 21 \\
\hline
\end{tabular}


Tabel 8

Totale uitstroom per opleidingssector naar bestemming

\begin{tabular}{|c|c|c|c|c|c|c|c|}
\hline $\begin{array}{l}\text { Opleiding- } \\
\text { niveau }\end{array}$ & Richting & $\begin{array}{l}\text { Totale uitstroom } \\
(\times 1.000)\end{array}$ & $\begin{array}{c}\text { Naar andere } \\
\text { baan } \\
\%\end{array}$ & $\begin{array}{c}\text { Werkloos } \\
\%\end{array}$ & $\begin{array}{c}\text { Niet- } \\
\text { participerend } \\
\%\end{array}$ & $\begin{array}{c}\text { Scholier } \\
\%\end{array}$ & $\begin{array}{c}\text { Pensioen } \\
\%\end{array}$ \\
\hline Basisonderwijs & Algemeen & 168 & 49 & 3 & 41 & 6 & 0 \\
\hline \multirow{5}{*}{ VMBO } & Algemeen & 144 & 47 & 4 & 38 & 11 & 0 \\
\hline & Landbouw/Techniek & 100 & 63 & 4 & 26 & 6 & 1 \\
\hline & Economisch/Juridisch & 42 & 51 & 3 & 40 & 6 & 0 \\
\hline & (Para)medisch & 77 & 43 & 4 & 46 & 7 & 0 \\
\hline & Onderwijs/Soc.Cultureel & 10 & 36 & 3 & 54 & 8 & 0 \\
\hline \multirow[t]{5}{*}{ MBO } & Algemeen & 106 & 60 & 3 & 27 & 10 & 0 \\
\hline & Landbouw/Techniek & 166 & 63 & 5 & 26 & 5 & 1 \\
\hline & Economisch/Juridisch & 199 & 66 & 2 & 28 & 4 & 0 \\
\hline & (Para)medisch & 150 & 54 & 3 & 36 & 7 & 0 \\
\hline & Onderwijs/Soc.Cultureel & 32 & 46 & 3 & 45 & 7 & 0 \\
\hline \multirow{5}{*}{$\mathrm{HBO} / \mathrm{WO}$} & Algemeen & 68 & 63 & 3 & 27 & 6 & 0 \\
\hline & Landbouw/Techniek & 46 & 69 & 3 & 23 & 5 & 0 \\
\hline & Economisch/Juridisch & 69 & 79 & 2 & 16 & 3 & 0 \\
\hline & (Para)medisch & 28 & 73 & 1 & 22 & 3 & 0 \\
\hline & Onderwijs/Soc.Cultureel & 102 & 62 & 3 & 31 & 4 & 0 \\
\hline Totaal & & 1.508 & 58 & 3 & 32 & 6 & 0 \\
\hline
\end{tabular}

Bron: ROA 
Tabel 9

Totale instroom per opleidingssector naar herkomst

\begin{tabular}{|c|c|c|c|c|c|c|}
\hline $\begin{array}{l}\text { Opleiding- } \\
\text { niveau }\end{array}$ & Richting & $\begin{array}{l}\text { Totale instroom } \\
\qquad(x 1.000)\end{array}$ & $\begin{array}{c}\text { Naar andere } \\
\text { baan } \\
\%\end{array}$ & $\begin{array}{c}\text { Werkloos } \\
\% \\
\end{array}$ & $\begin{array}{c}\text { Niet- } \\
\text { participerend } \\
\% \\
\end{array}$ & $\begin{array}{c}\text { Scholier } \\
\% \\
\end{array}$ \\
\hline Basisonderwijs & Algemeen & 142 & 48 & 14 & 29 & 9 \\
\hline \multirow{5}{*}{ VMBO } & Algemeen & 113 & 54 & 11 & 24 & 11 \\
\hline & Landbouw/Techniek & 89 & 66 & 9 & 10 & 15 \\
\hline & Economisch/Juridisch & 39 & 46 & 13 & 26 & 16 \\
\hline & (Para)medisch & 77 & 39 & 7 & 48 & 6 \\
\hline & Onderwijs/Soc.Cultureel & 9 & 26 & 16 & 25 & 34 \\
\hline \multirow[t]{5}{*}{ MBO } & Algemeen & 119 & 46 & 11 & 14 & 30 \\
\hline & Landbouw/Techniek & 162 & 60 & 10 & 10 & 20 \\
\hline & Economisch/Juridisch & 203 & 59 & 8 & 12 & 22 \\
\hline & (Para)medisch & 156 & 46 & 8 & 29 & 17 \\
\hline & Onderwijs/Soc.Cultureel & 33 & 37 & 10 & 18 & 35 \\
\hline \multirow{5}{*}{$\mathrm{HBO} / \mathrm{WO}$} & Algemeen & 62 & 63 & 10 & 25 & 2 \\
\hline & Landbouw/Techniek & 62 & 49 & 5 & 7 & $3 \overline{9}$ \\
\hline & Economisch/Juridisch & 105 & 49 & 4 & 8 & 40 \\
\hline & (Para)medisch & 45 & 44 & 2 & 13 & 41 \\
\hline & Onderwijs/Soc.Cultureel & 116 & 50 & 7 & 20 & 23 \\
\hline Totaal & & 1.533 & 52 & 9 & 19 & 21 \\
\hline
\end{tabular}

Bron: ROA 
Tabel 10

Opleidingsverdeling van de populatie en de stromen

\begin{tabular}{|c|c|c|c|c|c|c|c|c|}
\hline $\begin{array}{l}\text { Opleiding- } \\
\text { niveau }\end{array}$ & Richting & $\begin{array}{l}\text { Start } \\
\%\end{array}$ & $\begin{array}{c}\text { Uitstroom } \\
\%\end{array}$ & $\begin{array}{c}\text { Instroom } \\
\%\end{array}$ & $\begin{array}{c}\text { Netto-instroom } \\
\%\end{array}$ & $\begin{array}{c}\text { Uitbreidings- } \\
\text { vraag } \\
\%\end{array}$ & $\begin{array}{c}\text { Discrepantie }^{\mathrm{a})} \\
\%\end{array}$ & $\begin{array}{c}\text { Eindsituatie } \\
\%\end{array}$ \\
\hline Basisonderwijs & Algemeen & 8 & 11 & 9 & -103 & -35 & 5 & 8 \\
\hline \multirow[t]{5}{*}{ VMBO } & Algemeen & 7 & 10 & 7 & -124 & 6 & 84 & 6 \\
\hline & Landbouw/Techniek & 8 & 7 & 6 & -44 & -30 & -22 & 8 \\
\hline & Economisch/Juridisch & 2 & 3 & 3 & -12 & 2 & 10 & 2 \\
\hline & (Para)medisch & 4 & 5 & 5 & 1 & -6 & -9 & 4 \\
\hline & Onderwijs/Soc.Cultureel & 0 & 1 & 1 & -3 & 0 & 2 & 0 \\
\hline \multirow[t]{5}{*}{ MBO } & Algemeen & 5 & 7 & 8 & 52 & 20 & 1 & 5 \\
\hline & Landbouw/Techniek & 16 & 11 & 11 & -17 & 13 & 31 & 16 \\
\hline & Economisch/Juridisch & 14 & 13 & 13 & 18 & 30 & 36 & 14 \\
\hline & (Para)medisch & 9 & 10 & 10 & 27 & 16 & 10 & 9 \\
\hline & Onderwijs/Soc.Cultureel & 2 & 2 & 2 & 3 & 6 & 7 & 2 \\
\hline \multirow[t]{5}{*}{$\mathrm{HBO} / \mathrm{WO}$} & Algemeen & 3 & 5 & 4 & -22 & 3 & 18 & 3 \\
\hline & Landbouw/Techniek & 5 & 3 & 4 & 61 & 10 & -21 & 5 \\
\hline & Economisch/Juridisch & 6 & 5 & 7 & 143 & 35 & -30 & 6 \\
\hline & (Para)medisch & 3 & 2 & 3 & 68 & 9 & -26 & 3 \\
\hline & Onderwijs/Soc.Cultureel & 8 & 7 & 8 & 52 & 22 & 3 & 8 \\
\hline Totaal \% & & 100 & 100 & 100 & 100 & 100 & 100 & 100 \\
\hline
\end{tabular}

a) Een negatief getal duidt op een overschot

Bron: ROA 
Tabel 11

De matrix van uitstroom naar bestemming (procentuele verdeling per herkomst)

\begin{tabular}{|c|c|c|c|c|c|c|c|c|c|c|c|c|c|c|c|c|c|}
\hline \multicolumn{2}{|c|}{ Startsituatie } & \multirow[b]{2}{*}{$\begin{array}{r}1 \\
\%\end{array}$} & \multicolumn{10}{|c|}{ Beroepssector } & \multirow{2}{*}{$\begin{array}{l}\text { Werk- } \\
\text { loos } \\
\%\end{array}$} & \multirow{2}{*}{$\begin{array}{c}\text { Niet-parti- } \\
\text { ciperend } \\
\%\end{array}$} & \multirow{2}{*}{$\begin{array}{c}\text { Scholier } \\
\%\end{array}$} & \multirow{2}{*}{$\begin{array}{c}\text { Pensioen } \\
\%\end{array}$} & \multirow{2}{*}{$\begin{array}{l}\text { Totaal } \\
\text { aantal } \\
(\times 1.000)\end{array}$} \\
\hline & & & $\begin{array}{l}2 \\
\%\end{array}$ & $\begin{array}{r}3 \\
\%\end{array}$ & $\begin{array}{r}4 \\
\%\end{array}$ & $\begin{array}{r}5 \\
\%\end{array}$ & $\begin{array}{l}6 \\
\%\end{array}$ & $\begin{array}{r}7 \\
\%\end{array}$ & $\begin{array}{r}8 \\
\%\end{array}$ & $\begin{array}{r}9 \\
\%\end{array}$ & $\begin{array}{l}10 \\
\%\end{array}$ & $\begin{array}{l}11 \\
\%\end{array}$ & & & & & \\
\hline 1 & Pedagogische beroepen & 45 & 0 & 0 & 0 & 0 & 0 & 8 & 0 & 7 & 0 & 0 & 0 & 33 & 7 & 0 & 28 \\
\hline 2 & Culturele beroepen & 8 & 55 & 0 & 8 & 0 & 0 & 4 & 0 & 4 & 0 & 0 & 4 & 7 & 11 & 0 & 28 \\
\hline $\begin{array}{l}3 \\
4\end{array}$ & $\begin{array}{l}\text { Agrarische beroepen } \\
\text { Technische- en }\end{array}$ & 0 & 0 & 26 & 10 & 0 & 0 & 4 & 0 & 0 & 6 & 0 & 4 & 29 & 15 & 5 & 39 \\
\hline & industrieberoepen & 1 & 0 & 1 & 52 & 4 & 0 & 6 & 1 & 0 & 2 & 0 & 6 & 23 & 4 & 0 & 239 \\
\hline $\begin{array}{l}5 \\
6\end{array}$ & $\begin{array}{l}\text { Transportberoepen } \\
\text { (Para) medische }\end{array}$ & 0 & 0 & 1 & 7 & 45 & 0 & 6 & 0 & 0 & 4 & 0 & 5 & 25 & 8 & 0 & 73 \\
\hline 7 & $\begin{array}{l}\text { beroepen } \\
\text { Economisch-administra- }\end{array}$ & 0 & 0 & 0 & 0 & 0 & 64 & 8 & 0 & 0 & 8 & 0 & 0 & 14 & 6 & 0 & 49 \\
\hline & tieve beroepen & 0 & 1 & 0 & 4 & 0 & 1 & 56 & 2 & 1 & 3 & 0 & 4 & 24 & 3 & 0 & 320 \\
\hline $\begin{array}{l}8 \\
9\end{array}$ & $\begin{array}{l}\text { Informaticaberoepen } \\
\text { Sociaal-culturele }\end{array}$ & 0 & 0 & 0 & 2 & 0 & 0 & 14 & 58 & 0 & 0 & 0 & 5 & 14 & 7 & 0 & 29 \\
\hline 10 & $\begin{array}{l}\text { beroepen } \\
\text { Verzorgende- en dienst }\end{array}$ & 2 & 0 & 0 & 2 & 2 & 2 & 13 & 0 & 46 & 4 & 0 & 7 & 20 & 2 & 0 & 34 \\
\hline 11 & $\begin{array}{l}\text { verlenende beroepen } \\
\text { Openbare orde- en }\end{array}$ & 2 & 0 & 1 & 2 & 2 & 1 & 6 & 0 & 2 & 39 & 2 & 3 & 28 & 11 & 0 & 296 \\
\hline & veiligheidsberoepen & 0 & 0 & 0 & 0 & 8 & 0 & 0 & 0 & 0 & 0 & 33 & 33 & 17 & 8 & 0 & 11 \\
\hline 12 & Werkloos & 1 & 0 & 2 & 9 & 2 & 1 & 10 & 1 & 1 & 10 & 0 & 0 & 58 & 5 & 0 & 361 \\
\hline 13 & Niet-participerend & 3 & 1 & 2 & 5 & 1 & 4 & 11 & 1 & 1 & 24 & 0 & 32 & 0 & 15 & 0 & 341 \\
\hline 14 & Studerend & 2 & 0 & 4 & 14 & 4 & 6 & 16 & 3 & 1 & 24 & 1 & 7 & 19 & 0 & 0 & 388 \\
\hline
\end{tabular}


Tabel 12

De matrix van instroom naar herkomst (procentuele verdeling per bestemming)

\begin{tabular}{|c|c|c|c|c|c|c|c|c|c|c|c|c|c|c|c|c|}
\hline \multicolumn{2}{|c|}{ Eindsituatie } & \multicolumn{11}{|c|}{ Beroepssector } & \multirow{2}{*}{$\begin{array}{l}\text { Werk- } \\
\text { loos } \\
\%\end{array}$} & \multirow{2}{*}{$\begin{array}{c}\text { Niet-parti- } \\
\text { ciperend } \\
\%\end{array}$} & \multirow{2}{*}{$\begin{array}{c}\text { Scholier } \\
\%\end{array}$} & \multirow{2}{*}{$\begin{array}{l}\text { Totaal } \\
\text { aantal } \\
(\times 1.000)\end{array}$} \\
\hline & & $\begin{array}{c}1 \\
\%\end{array}$ & $\begin{array}{l}2 \\
\%\end{array}$ & $\begin{array}{l}3 \\
\%\end{array}$ & $\begin{array}{c}4 \\
\%\end{array}$ & $\begin{array}{l}5 \\
\%\end{array}$ & $\begin{array}{l}6 \\
\%\end{array}$ & $\begin{array}{l}7 \\
\%\end{array}$ & $\begin{array}{l}8 \\
\%\end{array}$ & $\begin{array}{l}9 \\
\%\end{array}$ & $\begin{array}{l}10 \\
\%\end{array}$ & $\begin{array}{l}11 \\
\%\end{array}$ & & & & \\
\hline 1 & Pedagogische beroepen & 26 & 4 & 0 & 3 & 0 & 0 & 3 & 0 & 2 & 15 & 0 & 7 & 22 & 19 & 49 \\
\hline 2 & Culturele beroepen & 0 & 70 & 0 & 0 & 0 & 0 & 10 & 0 & 0 & 0 & 0 & 5 & 10 & 5 & 22 \\
\hline 3 & Agrarische beroepen & 0 & 0 & 22 & 5 & 2 & 0 & 3 & 0 & 0 & 9 & 0 & 12 & 14 & 32 & 46 \\
\hline \multirow[t]{2}{*}{4} & Technische- en industrie- & & & & & & & & & & & & & & & \\
\hline & beroepen & 0 & 1 & 1 & 47 & 2 & 0 & 5 & 0 & 0 & 3 & 0 & 13 & 7 & 20 & 263 \\
\hline 5 & Transportberoepen & 0 & 0 & 0 & 11 & 40 & 0 & 2 & 0 & 1 & 7 & 1 & 11 & 5 & 21 & 81 \\
\hline \multirow[t]{2}{*}{$\begin{array}{l}6 \\
7\end{array}$} & $\begin{array}{l}\text { (Para) medische beroepen } \\
\text { Economisch-administratieve }\end{array}$ & 0 & 0 & 0 & 0 & 0 & 40 & 4 & 0 & 1 & 4 & 0 & 4 & 20 & 28 & 78 \\
\hline & beroepen & 1 & 0 & 0 & 4 & 1 & 1 & 49 & 1 & 1 & 5 & 0 & 10 & 10 & 16 & 367 \\
\hline 8 & Informaticaberoepen & 0 & 0 & 0 & 4 & 0 & 0 & 15 & 41 & 0 & 0 & 0 & 10 & 5 & 25 & 42 \\
\hline 9 & Sociaal-culturele beroepen & 5 & 3 & 0 & 2 & 0 & 0 & 9 & 0 & 40 & 13 & 0 & 11 & 11 & 6 & 39 \\
\hline 10 & Verzorgende- en & & & & & & & & & & & & & & & \\
\hline \multirow{2}{*}{11} & dienstverlenende beroepen & 0 & 0 & 1 & 1 & 1 & 1 & 3 & 0 & 0 & 33 & 0 & 10 & 24 & 27 & 347 \\
\hline & $\begin{array}{l}\text { Openbare orde- en velligheids- } \\
\text { beroepen }\end{array}$ & 0 & 0 & 0 & 0 & 0 & 0 & 0 & 0 & 0 & 41 & 30 & 0 & 0 & 28 & 12 \\
\hline 12 & Werkloos & 0 & 1 & 1 & 7 & 2 & 0 & 6 & 1 & 1 & 5 & 2 & 0 & 59 & 15 & 186 \\
\hline 13 & Niet-participerend & 2 & 0 & 2 & 10 & 3 & 1 & 14 & 1 & 1 & 15 & 0 & 37 & 0 & 13 & 558 \\
\hline 14 & Studerend & 1 & 2 & 4 & 7 & 4 & 2 & 7 & 1 & 1 & 23 & 1 & 13 & 34 & 0 & 144 \\
\hline
\end{tabular}

Bron: ROA 
Het moet opgemerkt worden dat in deze tabellen de percentages sterk bepaald kunnen worden door de 'geconstrueerde populatie' die gebruikt is voor de berekeningen.

De informatie uit tabel 9 kan ook anders gebruikt worden. In plaats van na te gaan in hoeverre de mobiliteit per opleidingstype verschilt, kan ook nagegaan worden in hoeverre de opleidingsverdeling van uitstroom en aanbod van elkaar verschillen. Deze informatie staat gepresenteerd in tabel 10 voor de hele beroepsbevolking. In principe is het nuttiger deze informatie per beroepssector te presenteren, omdat dan duidelijk wordt in hoeverre er sprake is van een verschuiving in de opleidingsachtergrond van de werkenden binnen een beroep. Als deze verschuiving voor een aantal jaren is bepaald, kan er op basis hiervan waarschijnlijk iets gezegd worden over upgradingstendensen in de diverse beroepssectoren. $\mathrm{Nu}$ is in tabel 10 te zien dat de opleidingsverdeling van de totale populatie niet wezenlijk verschuift, maar dat er wel sprake is van een hoger opleidingsniveau van het aanbod dan van de uitstroom.

\subsection{Verwachte baanmobiliteit}

In de vorige paragraaf is een uitsplitsing van de stromen op de arbeidsmarkt gegeven. Hierbij is voor de werkenden uitsluitend onderscheid gemaakt naar uitstroom naar een andere baan (al dan niet in hetzelfde beroep). In principe is het mogelijk om een veel gedetailleerdere opsplitsing te maken. In deze paragraaf wordt deze informatie gepresenteerd. Op basis van deze informatie kan nagegaan worden in hoeverre bepaalde beroepen optreden als leverancier voor andere beroepssectoren, of juist als bestemming voor werkzoekenden.

In tabel 8 en 9 wordt de procentuele verdeling van de uitstroom naar bestemming en de instroom naar herkomst gepresenteerd. Tabel 11 geeft deze informatie voor de uitstroom. In de tabel vallen een paar zaken sterk op: ten eerste dat bij de meeste beroepssectoren ongeveer de helft van de vertrekkende werknemers terugkeert binnen dezelfde sector. De overigen vertrekken naar andere beroepssectoren, of stoppen geheel met werken. Opvallend hierbij is de aantrekkingskracht van de technische- en industrieberoepen (sector 4) en de economisch-administratieve beroepen (sector 7). Opvallend is ook dat in de sector openbare orde en veiligheid slechts $33 \%$ van de bruto-uitstroom terugkeert in dezelfde sector. Ook in deze tabel valt het grote aantal niet-participerenden op dat terugkeert op de arbeidsmarkt. Het zou nader uitgezocht moeten worden welke mensen dit zijn (geslacht, leeftijd, opleidingsniveau). Waarschijnlijk zijn het vooral vrouwen van middelbare leeftijd en hogere opleiding die terugkeren naar een werkkring. Dit zou verklaren waarom vooral de administratieve en verzorgende beroepen hiervan profiteren.

Tabel 12 geeft in principe dezelfde informatie, maar dan de instroom uitgesplitst naar herkomst. Ook hier valt weer op dat minder dan de helft van de instroom betrekking heeft op de baan-baanmobiliteit binnen de beroepssector. Het merendeel wordt aangenomen uit andere sectoren. Hier blijkt dat sector 7 niet alleen een sector is met een grote aantrekkingskracht, maar ook een waarin werkgevers uit vrij veel andere sectoren hun personeel kunnen werven. Hier is ofwel sprake van een onscherpe afbakening in de classificatie, of het gaat hierbij om beroepen waarvoor relatief weinig vakspecifieke kennis noodzakelijk is. Duidelijk 
is ook weer de relatief grote instroom vanuit de groep niet-participerenden. Deze (verwachte) instroom is de oorzaak van de verwachte overschotten. Als deze instroom niet meegeteld wordt, omdat deze voor de werkgevers in eerste instantie niet als bruikbaar arbeidsaanbod gezien worden, vallen de overschotten in tabel 4 weg. Het totale ex-ante aanbod uit de groep niet-participerenden is namelijk ruim 180.000 mensen. Als dit aanbod buiten beschouwing gelaten wordt, is er sprake van een tekort van ca. 50.000 mensen, dat wil zeggen ca. $1 \%$ van het aantal werkenden.

Tot slot valt in tabel 11 en 12 op dat de situatie van voltijds scholier niet voor iedereen alleen maar een startsituatie is. Afgezien van codeerproblemen die hier op kunnen treden (belangrijkste activiteit), lijken er vanuit alle beroepssectoren overgangen naar een opleiding voor te komen, en ook vanuit de opleiding naar de meeste arbeidsmarktsituaties. De codeerproblemen kunnen voortkomen uit de CBS-definitie dat het aantal gewerkte uren per week bepalend is voor de belangrijkste activiteit: als dit meer dan 12 uur per week is, is men werkend. Hierdoor kunnen bijvoorbeeld scholieren met een baan met wisselende urenaantallen 'vrij eenvoudig' wisselen van arbeidsmarktpositie.

\subsection{Gebruiksmogelijkheden van de prognoses}

De prognoses die in de vorige paragrafen gegeven zijn, kunnen op verschillende manieren gebruikt worden om in de informatiebehoefte te voorzien. Op een aantal aspecten daarvan wordt in deze paragraaf ingegaan.

Allereerst geeft het overzicht van de verwachte discrepanties in paragraaf 5.2 inzicht in de verwachte knelpunten per opleidingstype en per beroep. Deze informatie kan gebruikt worden om aan te geven waar op korte-termijn problemen in de personeelsvoorziening te verwachten zijn, maar ook, waar mogelijkheden liggen voor werkzoekenden om een baan te vinden. In combinatie met gegevens uit de Statistische Bijlage van De arbeidsmarkt naar opleiding en beroep kan per beroepssector veel nauwkeuriger nagegaan worden om welke opleidingen het binnen de desbetreffende beroepssector gaat. Dit moet het ook mogelijk maken om de informatie die nu per opleidingssector en beroepssector gepresenteerd is ook voor lagere aggregatieniveaus te presenteren. Door na te gaan hoe de regionale spreiding van aanbod en vraag over het land verdeeld is, kan de informatie uit de voorgaande tabellen ook naar de regio's uitgesplitst worden. Vanwege de celvulling en dus de betrouwbaarheid van de cijfers, moet hierbij wel aangetekend worden dat het dan waarschijnlijk niet mogelijk is om een veel lager aggregatieniveau naar opleiding of beroep te realiseren.

Inzicht in de 'normale overgangen' die een werkende in zijn leven maakt, kan verkregen worden op basis van de gedetailleerde informatie over de stromen uit paragraaf 5.4, of op basis van de waargenomen mobiliteit uit het verleden, die weergegeven staat in tabel 1 in paragraaf 4.4. Deze informatie laat zien in hoeverre er sprake is van mobiliteit binnen bepaalde beroepen of opleidingen. Op basis hiervan kan een indicatie gegeven worden van de mate van (al dan niet gedwongen) mobiliteit waarmee werkenden geconfronteerd zullen worden. Deze informatie is enerzijds van belang voor de werkzoekenden, die op basis hiervan in kunnen schatten hoe hun loopbaan er uit zou kunnen zien, maar anderzijds ook 
voor de werkgevers, omdat ze kunnen zien uit welke beroepsgroepen op de arbeidsmarkt zij hun werknemers kunnen werven, maar ook naar welke beroepen hun mensen doorstromen. Omdat het model in principe is gebaseerd op gedragsvergelijkingen moet het mogelijk zijn om te simuleren wat er gebeurt met deze stromen als bijvoorbeeld de uitstroom van vrouwen wordt afgeremd. Dergelijke exercities gaan echter buiten de doelstelling van dit werkdocument.

Als duidelijk is bij welke beroepen er een (ex-ante) knelpunt zal ontstaan, kan de informatie over de te verwachten discrepanties en de te verwachten stromen gecombineerd worden: er kan dan op die manier per beroep een ruwe indruk verkregen worden van het type mensen waaraan behoefte is binnen een bepaald beroep. Dit levert de mogelijkheid om gericht te gaan werven in bepaalde sectoren, maar ook om na te gaan in welke mate niet-participerenden gebaat zijn bij aanvullende scholing. Het zou wel eens zo kunnen zijn dat er in een bepaalde sector behoefte is aan ervaren mensen met een bepaalde opleiding. De werkzoekenden zijn dan niet gebaat bij extra opleiding, maar wel met een toenemende mobiliteit van werkenden, zodat zij op een andere plek in kunnen stromen.

Op basis van de gegevens over de brutostromen uit paragraaf 5.3 en 5.4 kan daarnaast aangegeven worden in hoeverre er potentieel arbeidsaanbod uit de groep werklozen en nietparticiperenden te verwachten valt. Het is alleen de vraag of deze krachten ook feitelijk inzetbaar zijn. Met name werklozen en potentiële herintreders zouden wel eens minder inzetbaar kunnen zijn dan de schoolverlaters en de werkenden. In dat geval zouden werklozen en potentiële herintreders gebaat zijn bij ondersteunende opleiding voorafgaand aan de arbeidsmarktintrede. Om een indruk daarvan te verkrijgen, is het mogelijk om de scholingsverdeling van de instroom uit de schoolverlaters in een bepaald beroep te vergelijken met de verdeling van het opleidingsniveau van het aanbod uit de niet-participerenden. Als er met betrekking tot het opleidingsniveau geen of slechts een kleine mismatch bestaat, zal kunnen worden volstaan met het aanbieden van opfriscursussen, die de noodzakelijke vakkennis binnen de beroepssector weer op peil brengen. Als de mismatch groot is, zal substantiële bijscholing plaats moeten vinden. Als er onvoldoende aanbod van het gewenste opleidingstype is, zullen werkgevers uitwijken naar bijvoorbeeld schoolverlaters van een andere opleidingsrichting dan de oorspronkelijk gevraagde. Nader onderzoek naar deze substitutieprocessen in het kader van een dergelijk stromenmodel zal nog plaats moeten vinden.

Een laatste type informatie dat gegenereerd kan worden is aanvullende informatie over de mobiliteit: er kan nagegaan worden hoeveel mensen er volgens het model mobiel zijn, waar deze vandaan komen, en waar ze heengaan. Ook is duidelijk hoe groot de toename van de werkgelegenheid is. Op die manier kan een indicator geconstrueerd worden die de samenhang aangeeft tussen de mobiliteit en de veranderingen in de werkgelegenheid. Omdat het voor een sector van belang is hoe groot de mobiliteit van het personeel is (te groot is niet goed, maar te laag ook niet) kan dit zeer waardevolle informatie opleveren. Door deze informatie per opleidingstype te presenteren, kan ook een indicator geconstrueerd worden die de mate van arbeidsmarktmobiliteit weergeeft van mensen met die desbetreffende opleiding. Men kan dan nagaan of men dit ambieert, of juist niet, en zijn keuze daar op af- 
stemmen. Deze laatste informatie kan weer van belang zijn in het kader van de loopbaanoriëntatie.

Er past bij de nu gegenereerde informatie een aantal kanttekeningen. Ten eerste is het binnen het model in de huidige vorm niet goed mogelijk om vraag en aanbod uit elkaar te houden. Dit betekent dat het wel mogelijk is om stromen te voorspellen, maar dat het daarentegen niet is mogelijk om aan te geven of de mobiliteitspatronen een vraag- dan wel een aanbodachtergrond hebben. Er wordt in het voorgaande dan ook afwisselend over instroom en aanbod gesproken. Het is waarschijnlijk juister om te spreken over aanbod. De tweede kanttekening kwam al eerder aan bod. Voor de hier gepresenteerde cijfers is een prognosetermijn van een jaar gekozen. Om tot prognoses voor een tweede jaar te komen, zal eerst een populatie geconstrueerd moeten worden zoals die aan het einde van het eerste jaar zal ontstaan. Op basis hiervan kan dan een tweede prognosejaar berekend worden. Dit vereist echter een aantal keuzen: de uitbreidingsvraag die gehanteerd wordt, is afkomstig uit een arbeidsmarktprognose van het CPB die uitgaat van een marktevenwicht. In principe moeten de voorspelde veranderingen gelijk zijn aan de gewenste veranderingen (d.w.z. de uitbreidingsvraag). Omdat dit per definitie niet zo is (er zijn doorgaans ex-ante discrepanties) zal er een keus gemaakt moeten worden over de manier waarop voor de tweede periode de 'startpopulatie' geconstrueerd zal worden. De meest voor de hand liggende manier is om per beroep de tekorten/overschotten te verrekenen met de groep nietparticiperenden.

\section{Conclusies en suggesties voor een verdere ontwikkeling}

In toenemende mate bestaat er behoefte aan arbeidsmarktprognoses voor de korte termijn, in aanvulling op de in het kader van het Project Onderwijs-Arbeidsmarkt gegenereerde middellangetermijnprognoses. In dit werkdocument is allereerst aangegeven welke informatiebehoefte er bestaat die niet vervuld kan worden met het middellangetermijnmodel. Vervolgens is er een methodiek gepresenteerd waarmee prognoses gemaakt kunnen worden die wel in deze informatiebehoefte voorzien

In hoofdstuk 2 is aangegeven dat de behoefte aan informatie voortkomt uit drie gebruiksdoelen: scholingsbeleid, bemiddelingsbeleid en loopbaanoriëntatie. De gebruikers van de informatie zijn dus zowel de werkgevers, als de werknemers en de intermediairs op de arbeidsmarkt. Deze drie groepen zijn gebaat bij een antwoord op de vraag waar op korte termijn de knelpunten op de arbeidsmarkt zullen ontstaan. De belangrijkste insteek hierbij is de beroepsdimensie omdat het hier - in tegenstelling tot de studiekeuze in het initieel onderwijs - met name gaat om een oriëntatie op beroepen. Vervolgens is het van belang om zicht te krijgen op de mogelijke groepen die - al dan niet met behulp van scholing - ingezet kunnen worden om deze tekorten op te vangen. De informatiebehoefte van de werkzoekenden is veel minder gericht op de vraag waar de knelpunten zullen ontstaan. Zij hebben tenslotte hun eigen keuze al lang gemaakt. Voor hen is meer van belang welke kansen zij hebben gegeven hun opleidingsachtergrond: de baanzekerheid, en welke beroepen en loopbaantrajecten er voor hen openstaan. Alle gebruikers zijn dus gebaat bij informatie over 
mobiliteit op de arbeidsmarkt. Juist deze informatie is binnen het huidige informatiesysteem niet aanwezig.

Informatie en prognoses over mobiliteit op de arbeidsmarkt kunnen niet met behulp van de middellangetermijnmethodiek gegenereerd worden. Vandaar dat in dit werkdocument gekozen is om een micro-economisch gefundeerd brutostromenmodel als uitgangspunt te nemen. In hoofdstuk 3 is de structuur van een dergelijk model weergegeven. Er wordt onderscheid gemaakt tussen een aantal posities op de arbeidsmarkt (werkend, scholier, niet-participerend), en het model geeft een voorspelling voor de overgangskansen tussen deze posities. Hierbij wordt de overgangskans mede bepaalt door de huidige positie op de arbeidsmarkt, maar ook door een aantal persoonlijke kenmerken zoals leeftijd en opleiding. In een dergelijke brutostromenaanpak kan ook expliciet rekening gehouden worden met baan-baanmobiliteit. Dit maakt het mogelijk om uitspraken te doen over vacatureketens en loopbaanontwikkeling. In hoofdstuk 3 wordt ook aangegeven hoe de resultaten van een micro-economisch stromenmodel gebruikt kunnen worden om macro-economische arbeidsmarktprognoses te maken. Door de op microdata geschatte overgangskansen toe te passen op de totale populatie, kan een indicatie verkregen worden voor de optredende stromen, en de daar uit voortvloeiende discrepanties naar opleiding of beroep.

In hoofdstuk 4 wordt ingegaan op de empirische specificatie van het model. Uitgaande van microdata (het Sociaal Economisch Panel van het CBS) wordt een bestand gemaakt waarin alle relevante overgangen staan. Op basis van dit bestand worden de overgangskansen geschat. Er wordt hiervoor gebruik gemaakt van een drietal multinomialelogitmodellen. $\mathrm{Er}$ wordt een model geschat dat verklaart of er sprake is geweest van een verandering, en zo ja of dit baan-baanmobiliteit geweest is, of een overgang van werkend naar niet-werkend. Daarnaast is er een model dat - als er sprake is van baan-baanmobiliteit - de overgangskansen geeft naar de diverse beroepssectoren. Het laatste model geeft - als men niet-participerend wordt - de overgangskansen aan naar werkloos, niet-participerend en voltijds scholier. Hoofdstuk 4 gaat daarnaast ook in op het gehanteerde aggregatieniveau bij de schattingen.

Hoofdstuk 5 geeft vervolgens aan in welke vorm de schattingen van het brutostromenmodel gepresenteerd kunnen worden. Hierbij worden prognoses van discrepanties gegeven per beroeps- en opleidingssector. Daarnaast wordt aangegeven hoe de in- en uitstroom per beroepssector opgebouwd zijn. Tot slot wordt ingegaan op de verwachte baan-baanmobiliteit. Op deze manier kan voor de in hoofdstuk 2 geschetste gebruiksdoelen de relevante informatie gepresenteerd worden. De in dit werkdocument gepresenteerde resultaten zijn in de huidige vorm nog niet geschikt om in de informatiebehoefte te voorzien; het gehanteerde aggregatieniveau is nog te hoog, en de presentatie sluit nog niet optimaal aan bij de informatiebehoefte van de gebruikers. Er zijn dus nog een aantal aanpassingen aan het model en de presentatie van de resultaten noodzakelijk. Ook zijn er nog tal van inhoudelijke uitbreidingen die verder uitgewerkt kunnen worden. In theorie heeft de hier geschetste methodiek een vrij grote potentie, ook in richtingen die tot nu toe niet uitgewerkt zijn (o.a. regionale mobiliteit, de keuze voor het volgen van scholing). Er wordt hier 
nogmaals op gewezen dat de in dit document vermelde cijfers illustratief zijn en niet als prognoses voor een zeker jaar beschouwd kunnen worden.

Een punt dat niet zozeer van belang is voor het gebruik van de gegeneerde informatie, maar wel voor de toe te passen methodiek is die van de samenhang tussen de korte- en langetermijninformatie. De prognoses geven aan bij welke beroepen en opleidingen op korte termijn een tekort of overschot zal ontstaan. Hierop inspelen met behulp van scholing heeft echter alleen zin als de scholingsduur korter is dan de prognosetermijn. Ook in andere gevallen is het de vraag in hoeverre de ontwikkelingen die op middellange termijn plaatsvinden in de kortetermijnprognoses moeten worden verdisconteerd. Hierbij doet zich ook de vraag voor in hoeverre het kortetermijnrendement c.q. de kans op werk direct na afloop van de cursus richtinggevend moet zijn wanneer dit afwijkt van het verwachte rendement op de middellange termijn.

Er zullen in de toekomst een aantal stappen gemaakt moeten worden ten aanzien van de verdere ontwikkeling van het model. Hierbij moet een onderscheid gemaakt worden tussen het verder uitwerken van het huidige model en de te presenteren informatie enerzijds, en het verder ontwikkelen en uitbreiden van het model anderzijds. Een eerste aanpassing betreft de te gebruiken data. Daar waar mogelijk moeten de data van het SEP vervangen worden door beter geschikte data. Voor gegevens over omvang en samenstelling van de populatie moet gebruik gemaakt worden van de EBB. Voor de instroom van schoolverlaters zal gebruik gemaakt moeten worden van het Schoolverlaters Informatie Systeem. De waargenomen baan-baanmobiliteit in SEP is waarschijnlijk te hoog als gevolg van de panelopbouw van het bestand. Het verdient aanbeveling om daarvoor op termijn een retrospectief databestand te gebruiken, in principe zou het retrospectieve deel van de EBB zich daarvoor lenen. De gemaakte prognoses zullen zo snel mogelijk geëvalueerd moeten worden. Omdat de prognosetermijn relatief kort is, kan een evaluatie vrij snel na het maken van de prognoses gemaakt worden. Op basis van deze evaluatie kan het model op onderdelen aangepast worden. Te denken valt daarbij aan het opnemen van meerdere (of andere) verklarende factoren in het micromodel, maar ook aan het aanpassen van bijvoorbeeld het aggregatieniveau waarop de schattingen gemaakt zijn, door bijvoorbeeld een andere groepering van beroepen of opleidingen te gaan gebruiken. Dergelijke evaluaties kunnen zeer nuttig zijn bij het verder uitwerken en verfijnen van de prognosemethodiek. De uitwerking en verfijning van de methodiek kan in een aantal stappen uitgevoerd worden.

\section{Stap I: Het desaggregeren van de data, en het verbijzonderen van de prognoses naar de ROA-classificaties.}

Het model zoals het in dit stadium gebruikt kan worden is gespecificeerd op een hoog aggregatieniveau. Om echter te voldoen aan de informatiebehoefte moeten de resultaten op een lager aggregatieniveau gegenereerd kunnen worden. Hiervoor zijn diverse mogelijkheden denkbaar: enerzijds kan het aggregatieniveau van de data lager genomen worden, anderzijds kan nagegaan worden in hoeverre het mogelijk is om de resultaten via een vastecoëfficiëntenverdeling te verbijzonderen. Het grootste probleem dat hierbij lijkt te bestaan is 
het feit dat de ROA-opleidingsindeling gebaseerd is op een vijfcijferige SOI-codering die in de nu gebruikte data (SEP) niet voorhanden is.

Stap II: Het verder inhoudelijk uitwerken van de diverse gedragsrelaties, met name het 'ontrafelen' van vraag en aanbodfactoren in de waargenomen stromen.

Het model zoals het na stap I functioneert, bestaat nog steeds uit een relatief klein aantal gedragsvergelijkingen. Hier kan een aantal ontwikkelingen plaatsvinden: enerzijds een studie naar de vraag of er verschillen bestaan in het arbeidsaanbodgedrag tussen groepen met verschillende kenmerken, anderzijds de vraag of het model alle relevante verklarende factoren bevat. Bij deze stap kan ook aandacht geschonken worden aan het expliciet relateren van de mobiliteitsstromen aan de arbeidsmarktsituatie. De eerste vraag is een econometrische vraag, de tweede een meer economisch-inhoudelijke. Het resultaat van de eerste uitbreiding in deze stap kan het schatten van afzonderlijke modellen voor de deelgroepen zijn, het resultaat van de tweede stap het opnemen van andere verklarende factoren, waarbij mogelijk voor verschillende subgroepen verschillende factoren van belang zijn (kinderopvang is voor vrouwen - nog steeds - relevanter dan voor mannen).

Twee stromen die op basis van de nu opgedane ervaringen meer aandacht behoeven zijn de instroom van de schoolverlaters, en de uitstroom naar pensioen en VUT. Anderzijds lijkt het ook aan te raden om na te gaan in hoeverre het arbeidsaanbod van niet-participerenden reëel aanbod is. De nu gepresenteerde cijfers suggereren overschotten, terwijl de praktijk van alledag leert dat er eerder sprake is van knelpunten in de personeelsvoorziening.

Stap III: Onderzoeken van de mogelijkheden tot regionale verbijzondering van de resultaten, eventueel aangevuld met studie naar regionale mobiliteit.

Tot nu toe is de zeer gedetailleerd verbijzondering naar beroep en opleiding het speerpunt geweest. Op basis van het geaggregeerde model kan echter ook onderzocht worden in hoeverre er verbijzondering naar regio kan plaatsvinden. Dit moet dan wel voorafgegaan worden door een aantal afzonderlijke studies naar regionale mobiliteit: wat is de verklaring, hoe zijn de patronen? De bevindingen hiervan kunnen dan gebruikt worden om de resultaten van het model naar regio op te splitsen.

Stap IV: Het opnemen van om- en bijscholing in het model.

Het model zoals dat beschreven is kent geen verklaring van het volgen van niet-initiële scholing. Wel voor zover dit de voltijdsvariant betreft, maar niet de combinatie van werken en leren. Hiervoor kan een apart model geschat worden dat de deelname aan niveauverhogende of richtingveranderende scholing verklaart. Hoewel het over de volle breedte van de arbeidsmarkt slechts om relatief kleine aantallen gaat, zou het bijvoorbeeld voor het MBOniveau, en daarmee in feite ook voor het VMBO- en HBO-niveau, wel relevant kunnen zijn om zicht te krijgen op deze om- en bijscholing. 
Stap V: Onderzoeken in hoeverre het model bruikbaar is voor beleidssimulaties.

Behalve de vraag in hoeverre knelpunten op de arbeidsmarkt voorkómen of opgelost zouden kunnen worden, rijst soms ook de vraag wat de effecten zijn van bepaalde maatregelen of gedragsveranderingen. Omdat het hele model - in principe - gebaseerd is op micro-economische gedragsvergelijkingen, bestaat er de mogelijkheid dat het ingezet wordt voor microsimulatie. Dit zou het mogelijk moeten maken om beleids- of gedragswijzigingen door te rekenen, en te zien hoe dit effect heeft op de verwachte knelpunten (verg. Borghans e.a. 1998a).

Stap VI: Onderzoeken in hoeverre deelmarktinformatie (gericht op beroepen, sectoren opleidingen etc.) bruikbaar is om het model te verfijnen.

In een aantal onderzoeksprojecten van het ROA is verder ingegaan op de arbeidsmarktontwikkelingen op specifieke deelmarkten. Met name de stromen naar en vanuit de deelsegmenten vragen dan om aandacht. Meestal wordt voor dergelijke studies veel gedetailleerdere informatie gebruikt, namelijk op sector-, beroeps- of opleidingsniveau. In principe sluit het brutostromenmodel goed aan bij dit type vraagstellingen, en zou de gedetailleerdere informatie bruikbaar moeten zijn om het model te schatten en de resultaten te verbeteren. De vraag is echter welke sectorinformatie gebruikt kan worden en om het model te schatten en op welke manier dit zou kunnen gebeuren. Niet denkbeeldig is namelijk het gevaar dat deze informatie juist strijdig is met de geaggregeerde informatie.

Bovenstaande ontwikkelstappen geven een indruk van de manier waarop het in dit werkdocument gepresenteerde stromenmodel verder ontwikkeld zou kunnen worden. Uiteraard is het heel goed denkbaar dat als in de loop van de tijd duidelijk wordt dat de informatiebehoefte verschuift, hierop ingespeeld moet worden door andere ontwikkelingen voorrang te verlenen. Het geschetste model staat tenslotte nog maar in de kinderschoenen, en zal zijn waarde in de prognosepraktijk nog moeten bewijzen.

\section{Literatuur}

Borghans, L., A. de Grip en H. Heijke (1996), 'Labour Market Information and the Choice of Vocational Specialization', Economics of Education Review, Vol. 15, no. 1, pp. 59-74.

Borghans, L., F. Cörvers, M. de Steur, J.D. Vlasblom, H. Vermeulen, K. de Vos, en J. Weltevrede

(1998a), Stromen op de arbeidsmarkt in de Zorgsector, OSA-rapport, Den Haag.

Borghans, L., J. Delmee, P. Marey en J.D. Vlasblom (1998b), Toekomstverkenning Arbeidsmarkt en scholing tot 2007, Ministerie van Sociale Zaken en Werkgelegenheid, Den Haag.

Diephuis, B.J., H. Heijke en J.D. Vlasblom (2000), Determinants of labour market outflow and occupational mobility, a study on Dutch micro-data, paper gepresenteerd op ESPE 2000, Bonn.

Grip, A. de (1993), Regionaal Arbeidsmarkt Informatie Systeem Limburg. Een verkennende analyse, ROA-R-1993/6, Maastricht. 
Grip, A. de, A. Jacobs en J.D. Vlasblom (1999a), De inzet van niet-direct inzetbaar arbeidsaanbod bij knelpunten op de arbeidsmarkt, ROA-W-1999/2, Maastricht.

Grip, A. de, en J.D. Vlasblom (1999b), Toekomstverkenning arbeidsmarkt apothekersassistenten in de openbare apotheek, ROA-R-1999/7, Maastricht.

Maddala, G.S. (1983), Limited and Dependent Variables in Econometrics, Cambridge.

Researchcentrum voor Onderwijs en Arbeidsmarkt (1999a), De Arbeidsmarkt naar Opleiding en Beroep tot 2004, ROA-R-1999/8, Maastricht.

Researchcentrum voor Onderwijs en Arbeidsmarkt (1999b), De Arbeidsmarkt naar Opleiding en Beroep tot 2004, Statistische Bijlage, ROA-R-1999/8B, Maastricht.

Willems, E., L. Borghans en A. de Grip (1997), Exit or no entry: replacement demand and shrinking employment, paper gepresenteerd op EALE 1997, Aarhus.

Windmeijer, F. (1992), De regionale dimensie van de arbeidsmarkt, OSA-werkdocument W108, Den Haag. 